NBER WORKING PAPER SERIES

\title{
WHEN DID OWNERSHIP SEPARATE FROM CONTROL? CORPORATE GOVERNANCE IN THE EARLY NINETEENTH CENTURY
}

\author{
Eric Hilt \\ Working Paper 13093 \\ http://www.nber.org/papers/w13093 \\ NATIONAL BUREAU OF ECONOMIC RESEARCH \\ 1050 Massachusetts Avenue \\ Cambridge, MA 02138 \\ May 2007
}

I would like to acknowledge the helpful comments of Leah Boustan, Stanley Engerman, Carola Frydman, Zorina Khan, Naomi Lamoreaux, Petra Moser, Antoinette Schoar, and seminar participants at UCLA, Yale, Harvard, Columbia, UNC Chapel Hill, MIT Sloan, the NBER Summer Institute, the Economic History Association annual meetings, and the Cliometrics Society conference. Elira Kuka and Jaree Pinthong provided superb research assistance. The views expressed herein are those of the author(s) and do not necessarily reflect the views of the National Bureau of Economic Research.

(C) 2007 by Eric Hilt. All rights reserved. Short sections of text, not to exceed two paragraphs, may be quoted without explicit permission provided that full credit, including () notice, is given to the source. 
When did Ownership Separate from Control? Corporate Governance in the Early Nineteenth Century

Eric Hilt

NBER Working Paper No. 13093

May 2007

JEL No. G3,K22,M2,N21,N81

\begin{abstract}
This paper analyzes the ownership and governance of the business corporations of New York State in the 1820s. Using a new dataset collected from the manuscript records of New York's 1823 capital tax, and from the charters of the corporations, I analyze the ownership structures of the firms, and investigate the degree to which ownership was separated from control at the time. In contrast to Berle and Means's account of the development of the corporation, the results indicate that many of the firms were dominated by large shareholders, who were represented on the firms' boards, and held sweeping power to utilize the firms' resources for their own benefit. The oppression of minority shareholders was a significant problem in early corporate governance, and many of the firms configured their voting rights in a way that curtailed the power of large investors. A positive relationship between firm value and these voting rights configurations is found among the publicly-traded firms in the sample.
\end{abstract}

\author{
Eric Hilt \\ Wellesley College \\ Department of Economics \\ 106 Central Street \\ Wellesley, MA 02481 \\ and NBER \\ ehilt@wellesley.edu
}


When did the separation of ownership from control arise in American corporations? Was there an early period in the development of the American economy in which ownership and control were unified, and if so, how did the governance of these early corporations function? Such questions are difficult to answer, given the fragmentary nature of the records that survive from early businesses. The most influential history of corporate ownership in the United States is presented in Berle and Means's The Modern Corporation and Private Property (1932), which argues that legal, organizational and technological developments in the late-nineteenth and early-twentieth centuries eroded the power and influence of stockholders, and led to the emergence of large, diffusely-held enterprises controlled by professional managers, or by minority interests. In particular, Berle and Means claim that in the early nineteenth century, ownership and control were indeed unified, and they distinguish the corporations of their time from those of a hundred years earlier, in which "the number of shareholders was few; they could and did attend meetings; they were business-men; and their vote meant something." 1 Most of the subsequent literature on corporate governance has accepted Berle and Means's characterization of the history of American corporations, and its emphasis on developments in the late-nineteenth century leading to the separation of ownership from control (see, for example, Dodd (1938) or Coffee $(2001))^{2}$.

But the early history of American corporations is not well understood. By the end of the first quarter of the nineteenth century, thousands of businesses in all manner of industries had been granted corporate charters by American states, and especially beginning in the 1820s, a small but growing number of these firms had publicly-traded equity shares (Rousseau and Sylla, $2005)^{3}$. This era is generally regarded as a "statistical dark age," however, and although these firms were certainly much smaller than the large industrial enterprises that appeared in the latenineteenth century, relatively little is known about their ownership or governance. ${ }^{4}$ With the noteworthy exception of Werner (1986), who argues that control by management arose even in the early-nineteenth century, the governance of America's early corporations has been the focus of

\footnotetext{
${ }^{1} \mathrm{Pg} .135 \mathrm{n} .14$. The authors acknowledge the existence of textile corporations in Massachusetts with large numbers of owners in the 1830s, but claim that these enterprises "stood alone" at the time (pg. 12).

${ }^{2}$ Roe (1994) and Becht and Delong (2005) complement the analysis of Berle and Means by examining additional causes of the diffusion of American corporate ownership in the late-nineteenth and early-twentieth centuries.

${ }^{3}$ The total number of business incorporations in the United States for any year after 1800 is not known, but the data in Davis (1917), Evans, (1948) and Kessler (1948) indicate that well in excess of two thousand businesses were chartered prior to 1826 in the large but incomplete group of states covered by those volumes.

${ }^{4}$ The ownership structures of extremely small numbers of early corporations in specific industries, including textile manufacturing (Davis, 1958), turnpike roads (Majewski, 1996), banks (Wright, 1999), and whaling (Hilt, 2006), have been documented from the surviving records of individual firms, but even these studies are unable to analyze the governance of the firms in any detail.
} 
little research. In view of the importance of the historical legal origins of contemporary investor protections (see, for example, LaPorta, Lopez-de-Silanes, Shleifer, and Vishny, 1998), this gap in our understanding of early corporate governance is striking.

This paper analyzes the ownership and governance of a relatively large sample of early-nineteenthcentury firms, using a newly-collected dataset of all of the business corporations chartered in New York State through 1825. The main elements of the dataset were collected from the surviving records generated by New York's capital tax of 1823-28, which required all operating business corporations to submit a list of their stockholders to the state's comptroller. Many of these ownership lists survive in the New York State Archives, and have been matched to the charters of the corporations; to lists of corporate directors obtained from contemporary newspapers and city directories, and from surviving directors' minute books; and to price data of securities traded on the New York Stock and Exchange Board (NYS\&EB), the institution that would later change its name to the New York Stock Exchange, collected by Sylla, Wilson and Wright (2005). The extensive information in the dataset enables me to analyze the governance of the firms in some detail.

In particular, I examine a series of questions relating to the extent of separation between ownership and control at the time. The first question is: what rights or protections were offered to investors in these early corporations, and how did these rights influence the governance of the firms? Surprisingly, few of the firms were required to produce regular financial statements, and there were no financial reporting standards of any kind, beyond the common-law prohibition against fraud. Mandatory dividend payments were also imposed only infrequently. The voting rights specified in the charters were the most important means by which the stockholders could protect their interests, and the configurations of voting rights chosen varied considerably. About half of the firms offered one vote per share to their stockholders, whereas most of the others offered what might be termed "graduated" voting rights - the number of votes per share an investor was entitled to was a (weakly) declining function of the number of shares he or she held. ${ }^{5}$ In order to analyze the different configurations of votes specified in the charters I develop a simple index of shareholder voting rights, and analyze how the average values of the index varied across across industries.

The second question I examine is: to what extent did large shareholders control these corporations? And what was the relationship between the extent of control by large shareholders, on the one hand, and the governance institutions specified in the charters, on the other? Although the

\footnotetext{
${ }^{5}$ Davis (1917) documents the use of these measures in the earliest American corporations, and Dunlavy (2004) describes the political rhetoric surrounding their use.
} 
data do indicate the presence of substantial numbers of small investors in many of the corporations, in general, ownership was highly concentrated, and many firms appeared to have been dominated by large shareholders. As most large investors were represented on the firms' boards, the extent of managerial voting power was extremely high, with on average about $40 \%$ of the votes in the hands of the directors. The oppression of minority investors by large shareholders was therefore a central concern in the governance of these firms, as with the firms of the mid-nineteenth century (Lamoreaux and Rosenthal, 2006). In general, firms in the industries with the greatest ownership concentration specified voting rights with the lowest values of the voting index, whereas firms in industries where share ownership was most equally distributed specified one vote per share, which corresponds to the highest value of the index. This suggests that graduated voting rights were chosen at least in part in order to attract small investors by limiting the voting power of large shareholders.

The final question examined in the paper is: how did the protections of investors specified in the charters, and the concentration of ownership of the shares, influence the market value of the firms? Although securities price data from the period are perhaps less informative than those of modern stock markets, as the trading volume was relatively light, the market values of the firms provide a means to assess the consequences of dominance by large shareholders, or governance institutions designed to curtail that dominance, for the performance of the firms. The results indicate a positive correlation between firm values and voting rights provisions that limited the power of large shareholders, based on analysis of the within-industry variation. Moreover, a strong negative correlation between the degree of managerial ownership and firm value is found, which is consistent with insiders expropriating the outside shareholders' property.

In general the results indicate that even in the early decades of the nineteenth century, before the development of large industrial enterprises, and even before the emergence of railroads, there was significant separation between ownership and control. Berle and Means's (1932, pg. 70) typology of control structures is useful in characterizing the results: they distinguish between "(1) control through almost complete ownership, (2) majority control, (3) control through legal device without majority ownership, (4) minority control, and (5) management control," where each type represents successively greater degrees of separation between ownership and control. ${ }^{6}$ Although few if any of

\footnotetext{
${ }^{6}$ Berle and Means document that $44 \%$ of the 200 largest firms of their time were subject to management control (1932, p. 115). Although their argument has become strongly identified with the consequences of management control, even in their own sample the majority of firms were not subject to this form of control. Recent research has also shown that management control is not an accurate description of modern firms in most contries (LaPorta,
} 
the firms in the 1820s could be characterized as subject to management control, where ownership is so diffuse that no individual or group dominates the corporation through stock ownership, most of the firms in the dataset would have been characterized by Berle and Means as under minority control - a group of investors held sufficient numbers of shares to dominate the firm, because the rest of the shares were diffusely held. The problems associated with this form of control were much more acute in the 1820s than in later periods, however, because at the time there was little if any distinction between control and management. Early corporations were in general run by their directors - there were few hierarchical levels within the firms. ${ }^{7}$ As there were few if any legal constraints on self-dealing by directors at the time, an investor who controlled the management of a firm could easily harness its operations for his own benefit. Conflicts between large shareholders (insiders) and small shareholders (outsiders) were therefore the central concern in early corporate governance, and the protections offered to investors at the time were often designed to address this problem. Overall, the picture of corporate governance in the early-nineteenth century that develops is one of weak investor protections, and strong ownership concentration - a relationship entirely consistent with that found in modern economies (La Porta, Lopes-de-Silanes, Shleifer and Vishny, 2000).

The sample of corporations analyzed in this paper encompasses a relatively large number of enterprises in a broad range of industries, and represents the first systematic and consistent dataset on early corporate governance. But it comes from only one state. American corporation law falls mostly within the purview of state law, and the statutes and case law pertaining to corporations, along with the content of corporate charters, differed somewhat across states. ${ }^{8}$ Nonetheless New York's central role in the development of the American economy, and Wall Street's central role in America's financial markets, makes New York's corporations an appropriate focus for a study of corporate governance during this period. The early-nineteenth century was a period of rapid growth and dynamism for New York's economy: the population of the state increased approximately fourfold between 1790 and 1825, becoming the nation's most populous; the city of New York developed into the preeminent center of business and finance in the United States, surpassing

\footnotetext{
Lopez-de-Silanes, and Shleifer, 1999).

${ }^{7} \mathrm{On}$ the history of management structures and their development, see Chandler (1977).

${ }^{8}$ Several works have analyzed the development of the corporation law in particular states, including Massachusetts (Dodd, 1954), Maryland (Blandi, 1934), New Jersey (Cadman, 1949), and New York (Seavoy, 1982). Although none of these works provides the detailed tabulations of charter provisions that would be necessary to make systematic comparisons with the data presented in this paper, New York's corporation laws do not appear to be idiosyncratic in any important sense.
} 
Philadelphia; and the completion of the Erie canal in 1825 further invigorated commerce in across the state. ${ }^{9}$ Perhaps more importantly, New York was a great innovator in the area of corporation law, and enacted one of the earliest general incorporation acts of any significance for businesses, the 1811 act for manufacturing companies; the first limited partnership law (1821) and one of the first free banking laws (1838) in the United States; and several influential regulatory statues, such as the safety fund law for banks (1829). Many of these statutes influenced the subsequent development of corporation law in other states; in some cases entire New York statutes were copied wholesale. ${ }^{10}$

The next section of the paper presents an analysis of the voting rights configurations specified in early-nineteenth-century charters, and documents the governance institutions in the charters of all New York business corporations from the years 1790-1825. Section 2 documents the ownership structures of the corporations operating in 1826-27. Section 3 investigates the relationship between the governance institutions chosen by the firms, and their ownership structures. And section 4 presents an analysis of the relationship between the market values and the governance provisions of the publicly-traded firms in the sample. A detailed description of the sources and methods used in constructing the dataset is provided in the Data Appendix at the end of the paper.

\section{The Charters of New York's Corporations, 1790-1825}

\section{$1.1 \quad$ Historical Background}

In the early-nineteenth century, the privileges of corporate status for businesses could only be obtained by petitioning a state government for a charter, which would be granted by legislative act. Although New York began to liberalize its incorporation process with its 1811 general incorporation act for manufacturing companies, entrepreneurs in other industries still needed to obtain a special act of the legislature in order to incorporate. The process of obtaining a charter was often costly and time consuming, and the use of the corporate form was therefore confined to industries where incorporation was a legal requirement, as with banks, or where special corporate powers were crucial, as with insurance firms, some manufacturing firms, and public utilities such as turnpike roads,

\footnotetext{
${ }^{9}$ New York's population grew from 340,120 in 1790 to 1,614,458 in 1825 (French, 1860). On the early prominence of Philadelphia in American finance, see Wright (2005), and Hammond (1957). For a discussion of the development New York City's economy during this era, see, for example, Albion (1939), Myers (1931), and Miller (1962).

${ }^{10}$ For example, New Jersey adopted New York's 1811 general incorporation act for manufacturing companies with very few changes in 1816, and considered, but ultimately rejected, adopting an act similar to New York's 1838 free banking law in 1839 (Cadman 1949: pg. 21-27). Massachusetts adopted an act appointing commissioners for the supervision and inspection of banks, similar to some of the provisions in New York's 1829 safety fund law (Dodd 1954: pg. 276).
} 
bridge companies, and gas light companies. Banks were among the most politically contentious enterprises at the time, and banking charters were particularly difficult to obtain. ${ }^{11}$

If granted, a charter of incorporation would specify the powers available to the firm, the size of the capital stock and the par value of the shares, and the duration of the corporation's existence. The charters also included provisions that regulated the operations of the businesses, which varied by industry - bank charters, for example, often included provisions that restricted the interest rates that could be charged on loans, and limited their indebtedness; bridge and turnpike road company charters dictated the rates of toll that could be charged; and manufacturing charters specified the types of products the corporation was permitted to produce. ${ }^{12}$ In general, early corporations did not have the power to merge with other corporations or in any way amend their charters without seeking an additional legislative act. And in the years through 1825, none of New York's corporations were granted the power to issue any securities other than common stock, and the right to invest in the stock of other corporations was usually forbidden, except with insurance firms.

The governance institutions of corporations were prescribed in their charters. Most corporations were to be managed by an elected board of directors, who would, in turn, elect a president, and also possibly appoint a secretary or treasurer, from among their members. ${ }^{13}$ The board would usually have the authority, by majority rule, to write the corporation's by-laws, and generally run the firm. ${ }^{14}$ The charters sometimes also referred to salaried agents, cashiers, clerks, secretaries, tellers, and others who would be hired by the directors and might have assumed some managerial responsibilities. In general, however, most of the firms in industries such as banking, insurance, and bridges and turnpikes had very few employees, ${ }^{15}$ and although some of the manufacturing firms

\footnotetext{
${ }^{11}$ See Hammond (1957) and Bodenhorn (2006). Many firms resorted to obtaining banking powers through a backdoor route by first incorporating in a different industry, and then lobbying to have banking privileges added to their charter. Thus the New York Manufacturing Company became the Phoenix Bank, and the New York Chemical Manufacturing Company became Chemical Bank. The Bank of the Manhattan Company was created by including some vague and totally unrestrictive language about financial powers in the original 1799 charter of a water company.

${ }^{12}$ Many authors have ascribed particular importance to these limits imposed on the scope of the enterprise in early charters, and to the ability of the state legislatures to "safeguard" shareholders by dictating the terms of charters. See, for example, Berle and Means (1932, p. 131 and 134.) In a related and important work, Roe (1994) argues that later regulations prohibiting banks and insurance companies from holding securities, motivated by populist politics, prevented them from becoming powerful blockholders, and thus playing a more effective role in the governance of nonfinancial corporations.

${ }^{13}$ For 15 of the corporations, mostly water companies, no board of directors was specified, although even for those firms some kind of elected office, such as a treasurer, was created.

${ }^{14}$ The directors' decision-making rules specified in the firms' by-laws often had important implications for the firms' performance. For example, Meissner (2005) found that the voting rules governing loan approval in early banks had significant effects on the rates of return earned by the banks' shareholders.

${ }^{15}$ For example, the directors' minutes of the Bank of America, the state's largest bank, indicate that in 1813 it had only 13 salaried employees, including the president (Citigroup Archives, New York NY.) The directors' minutes of turnpike road companies record entries where the directors themselves hire contractors to build the road, co-sign loans on the firm's behalf, and supervise the conduct of the gate keepers (Directors Minutes, Albany \& Schenectady
} 
did have as many as 300 employees, the management of these enterprises probably had very few hierarchical levels, and in many cases the directors supervised even the day-to-day operations of the firms. ${ }^{16}$

As in modern firms, the stockholders' elective franchise was the principal mechanism by which corporations were governed. For nearly all of the corporations in the sample, the charters required elections of the entire board - there were no "classified" or staggered boards - to be held annually. ${ }^{17}$ As we will see, however, stockholders in early corporations enjoyed few other legal protections, and were usually not even guaranteed the right to see annual financial statements. ${ }^{18}$ In the absence of other safeguards, the election of directors assumed preeminent importance for the stockholders in defending their interests. And the conduct of the elections, including the voting rights of stockholders, were often specified in great detail in the charters.

In what was likely an effort to control the power of large shareholders, the voting rights specified in the charters often did not grant one vote per share, but instead granted a number of votes per share that was a (weakly) decreasing function of the number of shares held. Attempts to control the power of large shareholders in this way date back the earliest history of the business corporation in England (see the examples in Scott, 1912), and some of the voting rights schemes adopted in New York during this period resemble those devised hundreds of years earlier. The next section presents a simple analysis of these voting rights schemes, and develops an index of voting rights to be used in the empirical analysis that follows.

\subsection{Voting rights of stockholders}

Consider the charter for the Bank of New York, written by Alexander Hamilton. For the election of directors, it specifies the following:

\footnotetext{
Turnpike Road, New-York Historical Society, New York NY.)

${ }^{16}$ An advertisement in the 1826 Longworth's New York City Directory for the Sterling Company, a manufacturer of iron goods, boasts of having 350 employees; the 1832 Census of Manufactures lists at least one other firm of that scale in New York State, the Peru Iron Company. The director's minutes of manufacturing firms often record the directors deciding on the purchase of raw materials and equipment, hiring managerial employees and mechanics, and supervising the sale of output (Directors' Minutes, Oneida Manufacturing Society, 1820-56, Oneida Historical Society, Utica NY.) On the development of managerial systems and hierarchies in corporations, see Chandler (1977).

${ }^{17}$ The possible exception arises from the 1811 general incorporation act for manufacturing companies which did not explicitly require annual elections of directors. Angell and Ames (1832), the first American treaties on corporation law, argues that when the charter is silent on this issue, elections can be held "when the occasion requires it" (p. 66). On staggered boards and firm value in modern firms, see Bebchuck and Cohen (2005).

${ }^{18}$ The shareholders in a corporation possessed a common-law right to see its books (Angell and Ames, 1832, p. 408), but this right was mostly likely costly or even impossible to enforce in some circumstances.
} 
each stockholder shall be entitled to a number of votes proportioned to the number of shares which he or she shall have held in his or her own name...according to the following ratio's [sic] that is to say, at the rate of one vote for each share not exceeding four, five votes for six shares, six votes for eight shares, seven votes for ten shares, and one vote for every five shares above ten. ${ }^{19}$

Such configurations of voting rights, which might be termed "graduated voting rights" schemes, granted one vote per share when small numbers of shares were held, but then after some threshold, a shareholder was entitled to less than one vote per share. Some were simpler than that of the Bank of New York; most turnpike corporations, for example, allowed one vote per share for up to 10 shares, and then one vote for every five additional shares held. Other versions added a maximum number of votes for any stockholder. But in every case we can think of the charter as specifying a function, $v(n)$, which determines the number of votes to which an investor holding $n$ shares would be entitled. For enterprises that chose one vote per share, $v(n)=n$, but in the charters of many corporations like the Bank of New York, for values of $n$ above some threshold, $v(n)<n$.

The graduated voting rights granted to stockholders in some early-nineteenth-century corporations were somewhat more complex than the allocations of votes considered in the modern theoretical literature on voting rights (see, for example, Harris and Raviv (1988) and Grossman and Hart (1988)), because they caused the relative voting power of each shareholder to become an endogenous function of the entire distribution of the shares. In particular, the power of large shareholders was diminished by these schemes only when small shareholders were also present. For a firm with stockholders who each hold equal stakes, whether they are large or small, graduated voting rights will produce exactly the same relative voting power for each stockholder as one vote per share: the nominal number of votes for each shareholder will be reduced, but each investor's share of the total votes will be the same. Only in the presence of small shareholders, who might receive as much as a full vote per share, is the voting power of large investors diminished. This implies that impact of graduated voting rights can only be assessed once the distribution of share ownership is known.

We can, however, construct an index of the potential of a given voting rights configuration to reduce the power of large shareholders. A simple way to motivate this index is to plot a typical $v(n)$ function - that is, a function specifying the number of votes a stockholder is entitled to when $n$ shares are held-and also votes per share, or $\frac{v(n)}{n}$, for increasing values of $n$. Figure 1 plots $v(n)$ and $\frac{v(n)}{n}$ for two firms, one with one vote per share, labelled $v_{1}(n)$, and one with a graduated

\footnotetext{
${ }^{19}$ New York Laws, 1791, ch. 37. This is similar to Hamilton's scheme for the voting rights of stockholders in his proposal for a "National Bank," in which he also offers an extended analysis and justification of these schemes. See Davis (1917, p. 324).
} 
Figure 1:

Voting Rights: One Share, One Vote vs. Graduated Voting Rights

(a) Votes

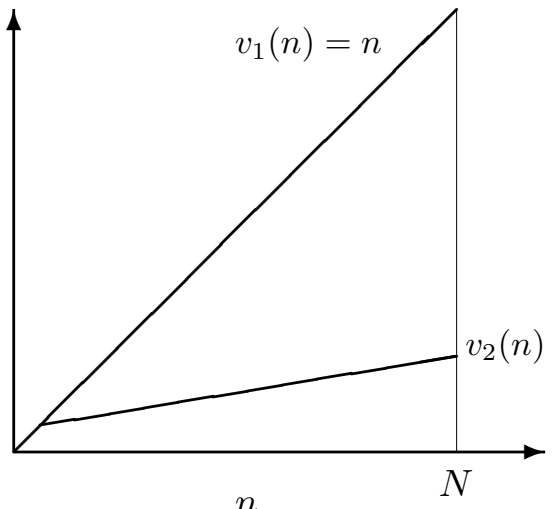

(b) Votes/Share

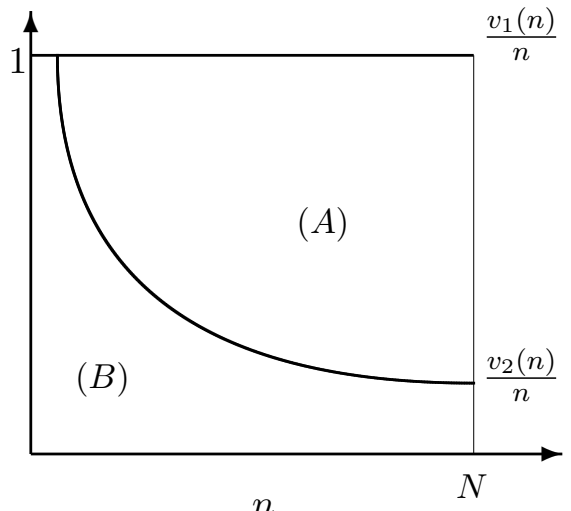

voting rights scheme, $v_{2}(n)$. Both firms are assumed to have a total of $N$ shares. The $v_{2}(n)$ function plotted is that employed in most turnpike road companies, and was the most common graduated voting rights scheme chosen. As panel (a) illustrates, with the graduated voting rights scheme, the slope of the line representing the number of votes a shareholder is entitled to becomes much flatter than the line representing one vote per share once a fairly low threshold of holdings is reached. As panel (b) of the figure makes clear, for a holder of a large block of shares, the number of votes per share could be substantially reduced by these schemes. In the presence of many shareholders holding small enough stakes so that they received a full vote for each share they held, the relative power of a large shareholder would be substantially reduced by this scheme.

In panel (b), the area below the $\frac{v_{2}(n)}{n}$ line, denoted (B), will be increasing in the number of votes to which holders of large stakes are entitled. This suggests that the relative fraction of the total area in the figure taken up by $(\mathrm{B})$, or $\frac{(B)}{(A)+(B)}$, could serve as an index of the potential voting power of large shareholders. Formally, this is calculated as:

$$
V_{i}=\frac{1}{N} \sum_{n=1}^{N} \frac{v_{i}(n)}{n} .
$$

The index can assume any value between 0 and 1, and can be thought of as measuring the voting scheme's potential to reduce the power of large shareholders; low values of the index signify potentially substantial reductions in relative votes in the presence of small shareholders. Corporations choosing voting rights with a low value of this index effectively grant more cash flow rights than 
voting rights to large shareholders, and more voting rights than cash-flow rights to small shareholders. Thus these measures have the opposite effect of the "control-enhancing mechanisms" of founding families identified in some modern corporations (see, for example, Villalonga and Amit, 2006; and LaPorta, Lopez-de-Silanes, and Shleifer, 1999).

A corporation choosing a voting rights scheme with a low value of the index creates an obvious incentive for investors to hold their shares in many names other than their own, in order wield a larger number of votes. Although such behavior was documented among the shareholders of the Second Bank of the United States - the privately-owned, quasi-central bank charted by the federal government in 1816, which had a graduated voting rights scheme that was extremely punitive towards large shareholders (Hammond, 1957) - the extent to which large shareholders circumvented the voting rights configurations of other business corporations in this way is not known, and will be investigated in the empirical analysis below.

Also, to the extent that these measures were not circumvented, their effect on the quality of management chosen, or firm value, is potentially ambiguous. On the one hand, they clearly limit the power of large shareholders, and if the expropriation of outside shareholders by insiders who held large stakes was a common problem, then voting rights that tipped the balance of power toward small shareholders might have raised the value of the firm. On the other hand, such measures would insulate the firm from the forces generated by the market for corporate control, and in particular would make it quite difficult for a large investor to purchase a controlling stake in the firm. The relationship between the choice of voting rights configuration and firm value will also be investigated in the empirical analysis below.

\subsection{Governance provisions in the charters}

From 1790 to 1825, New York State granted charters of incorporation to 812 businesses. The specifications of voting rights in the charters, along with other governance provisions, are summarized in table 1 . As indicated in the table, in about $80 \%$ of the charters, the right to vote by proxy in the election of directors was guaranteed. ${ }^{20}$ At the time, proxy votes (like all votes) were cast in person, so a shareholder wishing to vote by proxy would send another individual in his or her stead.

The charters sometimes also contained other provisions regulating the composition or the actions

\footnotetext{
${ }^{20}$ New York's courts later held that the right to vote by proxy could only be granted in a charter (Philips $v$. Wickham, 1 Paige 590 New York (1829)). Prior to this decision in 1829, the rights of shareholders with respect to proxy voting, when it was granted by a firm's bylaws rather than its charter, were uncertain. Dodd (1954), for example, mentions that the Connecticut courts held in 1812 that bylaws that permitted proxy voting were valid.
} 
Table 1:

Charter Governance Provisions: Industry Means, 1790-1825

Mean values of selected governance provisions for all 812 business corporations chartered in New York, 1790-1825, and by industry. The industry category Banks encompasses all institutions permitted to issue banknotes, and therefore includes firms that have a fraction of their capital invested in other industries. The insurance and finance companies include all insurance companies, along with the five loan or "lombard" companies that were permitted to make collateralized loans, but were forbidden from issuing banknotes. As insurance companies were also permitted to issue loans, in practice these institutions were quite similar. The category All Others includes 28 water companies, 18 canals, 4 mutual savings banks, a hotel, 15 steamboat or ferry companies, 2 trading companies, 4 gas light companies, a financial exchange, and 11 mining companies.

\begin{tabular}{|c|c|c|c|c|c|c|c|}
\hline & $\begin{array}{c}\text { All Charters, } \\
1790-1825 \\
(N=812)\end{array}$ & $\begin{array}{c}\text { Banks } \\
(N=43)\end{array}$ & $\begin{array}{l}\text { Bridges } \\
(N=86)\end{array}$ & $\begin{array}{l}\text { Insurance } \\
\& \text { Finance } \\
(N=74)\end{array}$ & $\begin{array}{c}\text { Manu- } \\
\text { facturing } \\
(N=221)\end{array}$ & $\begin{array}{l}\text { Turnpikes } \\
(N=304)\end{array}$ & $\begin{array}{c}\text { All } \\
\text { Others } \\
(N=84)\end{array}$ \\
\hline \multicolumn{8}{|l|}{ Election of Directors } \\
\hline Voting by proxy guaranteed & .82 & 1 & .21 & .97 & .97 & .89 & .56 \\
\hline \multicolumn{8}{|l|}{ Voting rights categories: } \\
\hline One vote/share & .48 & .63 & .55 & .93 & .91 & .01 & .53 \\
\hline Graduated voting rights & .45 & .26 & .41 & .03 & .02 & .98 & .23 \\
\hline One vote/shareholder & .02 & 0 & .01 & .01 & 0 & 0 & .18 \\
\hline Not specified & .05 & .12 & .03 & .03 & .07 & .02 & .07 \\
\hline Index of voting rights $\left(V_{i}\right)$ & .63 & .74 & .70 & .96 & .99 & .23 & .76 \\
\hline \multicolumn{8}{|l|}{ Actions Required of the Board } \\
\hline Mandatory dividends & .40 & 0 & .20 & 0 & 0 & .98 & .13 \\
\hline Annual financial statements & .14 & .40 & .23 & .41 & .13 & .01 & .18 \\
\hline \multicolumn{8}{|l|}{ Composition of the Board } \\
\hline Number on board & 9 & 13 & 6 & 20 & 5 & 8 & 8 \\
\hline Local residency requirement & .04 & .35 & .01 & .05 & .01 & .01 & .10 \\
\hline Shareholding requirement & .78 & .93 & .88 & .90 & .46 & .99 & .61 \\
\hline
\end{tabular}

of the board. For example, the directors were usually ( $78 \%$ of the time) required to own stock in the firm, and more rarely ( $4 \%$ of the time) imposed a specific local residency requirement for some or all of the directors. About $40 \%$ of the firms' boards were required to pay out all profits out as dividends, leaving no discretion over retaining earnings. ${ }^{21}$ And finally, $14 \%$ of the charters required the management of the firm to produce annual financial statements, either at the shareholders' annual meeting, or in a filing to the state government. ${ }^{22}$

The voting rights of the shareholders were generally specified in precise detail in the charters. In $48 \%$ of them, each share was entitled to one vote, irrespective of the number of shares held. For $46 \%$ of the charters, a "graduated" voting rights system was specified. For $2 \%$ of the firms, each shareholder was granted one vote, and, finally, for $4.7 \%$ of the firms, the votes of shares were not specified at all. In the latter case, with no guarantee of voting rights for the shares in the charter, most corporations likely specified the voting rules for shareholders in their bylaws; indeed, at least

\footnotetext{
${ }^{21}$ For another $32 \%$ of the firms, their charter stated that it "shall be the duty" of the directors to pay dividends out of the firms' earnings, but the directors were given total discretion over the amount.

${ }^{22}$ Another $0.4 \%$ of the firms were required to produce financial statements every three years, and $38 \%$ of the firms, mostly the turnpike road companies, were required to produce a single set of financial statements once they commenced operations, and then never again.
} 
one charter from the era specified parameters within which the voting rights chosen in the bylaws must fall. ${ }^{23}$ For all the firms in the sample where the voting rights of stockholders were specified, the average value of the voting rights index $V_{i}$ is .63.

We can begin to understand the intentions behind the governance provisions in the charters by comparing those selected in different industries, as in the further columns of table 1, where summary statistics are presented for six broad industry categories. The columns in the table indicate that there was substantial variation across industries in the style of governance institutions chosen. ${ }^{24}$ Manufacturing corporations, for example, almost always granted their investors one vote per share, only rarely required annual financial statements, and never mandated that all profits had to be paid out as dividends. Manufacturing firms also had the smallest boards, and imposed the requirement of share ownership by directors with the lowest frequency. As we will see below, these governance provisions reflected an ownership structure that was quite different than that commonly found in other industries.

In contrast, banks and insurance companies, whose financial powers created ample opportunities to defraud investors and creditors, and to disrupt the payments system, were the only firms whose charters mandated annual financial statements with any regularity, and even in these industries the requirement was imposed only $40 \%$ of the time. Firms in these two industries had very large boards, and the directors were never required to pay out all profits as dividends. The one important difference between the charters in banking and insurance is in their voting rights: whereas the average value of the index of voting rights for insurance firms is .96, in banking it is .74, reflecting the use of some graduated voting rights schemes.

In turnpike road companies, and to a lesser extent in bridge companies, graduated voting rights were heavily used, as was the requirement of mandatory dividend payments of all profits. ${ }^{25}$ Overall the lowest values of the voting index (reflecting voting rights configurations with the greatest potential to reduce the power or large shareholders) were found in turnpikes, bridges, and banks. One might imagine that the charters of firms in these industries were designed to attract the

\footnotetext{
${ }^{23}$ Laws of New York, 1826, Ch. 202. New Jersey's supreme court later held that bylaws could not override a common law rule of one vote per person when a charter did not specify voting rights (Taylor v. Griswold, 14 N.J.L. 222 (Sup. Ct. 1834)). Ratner (1970), however, argues persuasively that the common law actually had no clear rule with respect to stockholders' voting rights. Moreover, Angell and Ames (1832, p. 64) point to cases that held that corporations were free to regulate their election in bylaws when the charter was silent on the issue.

${ }^{24}$ Gillan, Hartzell and Starks's (2006) analysis of a large sample of modern firms identifies somewhat similar clustering in firms' choices of governance mechanisms, although they do not link the clusters to the firms' industries.

${ }^{25}$ In the case of turnpikes, these outcomes reflect the requirements imposed by the 1807 general regulating act for that industry; all turnpike companies chartered after 1807 had these provisions imposed on them by the act.
} 
participation of small shareholders by offering them some measure of protection from dominance by large shareholders. Alternatively, the legislature may have regarded the control of these enterprises, and in particular the potential for large shareholders to abuse that control, as a matter of public concern: the route of a turnpike road, the placement of a bridge, and of course the notes or loans issued by a bank all might have created opportunities for private gain by a dominant shareholder at the expense of small investors, or the community, in a way that was far less likely to be true of firms in industries such as manufacturing.

\subsection{Other Governance Statutes}

The rights of shareholders expressed in the charters were to a limited extent supplemented by statute laws enacted during the period, but in general the rapid proliferation and increasing sophistication of corporations outpaced the efforts of the legislature and the courts to protect the interests of investors. There were, for example, still relatively few statutes governing the behavior of corporate directors. Moreover, the notion that a corporate charter was a contract between the state and the firm that could not be impaired, as held by the U.S. Supreme Court in its 1819 Dartmouth College decision, made it difficult for the state to impose measures such as a financial reporting or inspection requirement on institutions whose charter did not already include such a provision.

The ability of the state to enforce its statutes was also limited, as the state government had only skeletal administrative offices. For example, many insurance companies, in violation of the state's restraining statutes and also in violation of their charters, issued bonds or notes designed to circulate as bank notes, offered discount loans, and generally assumed the powers of banks. ${ }^{26}$ Even after the restraining statutes were strengthened, and subsequent court decisions removed any doubt regarding the legality of these actions, the New York Senate's finance committee found in 1825 that these practices remained fairly widespread. ${ }^{27}$ Even on matters that were simpler to monitor, such as the use of the general incorporation statute, the limits of the law with respect to the industries within which the firms had to operate were violated, with little apparent consequence. ${ }^{28}$ And in other cases, safeguards or regulations were circumvented. Most charters of financial companies, for example, included a requirement that a minimum amount of capital be paid in before the business

\footnotetext{
${ }^{26}$ See New York Firemen Insurance Company v. Ely, 2 Cow 678 New York (1824), for details of one prominent episode.

${ }^{27}$ Albany Argus, 19 April 1825.

${ }^{28}$ The statute permitted firms to incorporate in the production of very specific categories of textiles, metals, and glass. And yet the "Farmers Brewery" was incorporated in Brooklyn in 1817 (Records of the state comptroller, New York State Archives.)
} 
could commence operations. These regulations seemed to presume that the payments would be made in specie, but instead such payments were nearly always made notes of various kinds, or pledged securities. ${ }^{29}$

Notwithstanding these limitations, the state did enact a highly significant piece of legislation in 1825 to protect the rights of shareholders and creditors. The act required that dividends could only be paid out of firms' profits; limited the indebtedness (relative to paid-in capital) that any firm could take on, and made directors personally liable for any indebtedness in excess of this amount; and imposed rules on the conduct of the election of directors, such as the requirement that the stock transfer books (which list the shareholders eligible to vote in elections of directors) be open to inspection. ${ }^{30}$ In response, a substantial body of case law relating to the election of directors began to develop, as the courts interpreted this law in the context of different practices employed by insiders seeking to disenfranchise other shareholders. ${ }^{31}$ In the following years, the state's regulations of corporations became more sophisticated, first in the Revised Statutes of 1828, which strengthened and expanded the 1825 law, and later with the introduction of the safety fund law for banks in 1829 .

In many respects, the rights of shareholders in early-nineteenth-century New York were relatively weak: many fraudulent practices in the elections of directors where not made illegal until the statute of 1825, and even then, the impact of the law took time to evolve; most corporations were not obligated to present their investors with financial statements; and the state struggled to rein in corporations that violated even the most politically sensitive laws, such as those regulating entry into banking. Directors of financial corporations routinely "hypothecated" their shares, meaning that they used their shares as collateral to borrow from the company and were often its debtors, rather than investors. ${ }^{32}$ The shares of many banks and insurance companies were traded on the New York Stock and Exchange Board, but the exchange itself had no listing requirements at the time, and did not provide meaningful safeguards for investors. Nonetheless, many corporations

\footnotetext{
${ }^{29}$ See the discussion in Hammond (1957). The descriptions of the financial transactions of some companies that went bankrupt in the New York Evening Post of 22 December 1826 mentions firms where none of the payments were made in specie.

${ }^{30}$ Other provisions of the law included many specific regulations of banks, and penalties for violating the terms of the charter. Laws of New York, 1825, ch. 325.

${ }^{31}$ Among such practices that the courts took up were directors attempting to use pledged shares to vote (Ex parte Willcocks 7 Cow 402 New York (1827)) using shares for which they were only trustees to vote (Ex parte Holmes 5 Cow 426 New York (Sup Ct 1826)), and using treasury shares to vote (Ex parte Desdoity 1 Wend 98 New York (1828)). These practices will be discussed below.

${ }^{32}$ See Lamoreaux (1994), and also Hammond (1957), who points out that even the investment of the federal government in the Bank of the United States was immediately hypothecated.
} 
created during the period successfully attracted investments from large numbers of shareholders.

In the next section, I describe the data collected from the records of New York State's capital tax, which will be used to analyze the ownership of these corporations.

\section{New York's Corporations in 1826-27 and Their Ownership}

In 1823, the New York legislature passed a law that exempted individuals' stock holdings from taxation, and instead levied a tax on the paid-in capital of incorporated companies, payable by the corporations themselves. The comptroller's ledgers of corporations, shareholdings, and tax payments, along with the stockholder lists submitted by many corporations, survive in the New York State Archives.

Of the 812 companies granted charters in New York in 1825 or before, the comptroller's office found that only 282 were in operation in 1826 or 1827.33 Table 2 presents the industries, reported paid-in capital, and location of the operating firms. In total, the capital of all operating corporations was about $\$ 48$ million, and the state's 95 banks and insurance companies accounted for about $\$ 39$ million or $81 \%$ of that total. There were 67 manufacturing firms, 63 turnpikes, 36 bridges, and small numbers of firms in other industries such as gas lighting, steamboats, and water works. The data in the table indicate that there was significant variation in the average sizes of the corporations across industries, with the largest companies in banking and finance, and the manufacturing corporations and turnpikes and bridges much smaller.

Turning to the lower panel of the table, of these 282 corporations, 74 (26\%) were located in New York City, and they had total capital of $\$ 34$ million, or about $71 \%$ of all corporations' capitala consequence of the fact that most of New York City's firms were large banks and insurance companies. In general, the remaining counties with significant numbers of corporations were located either along the Hudson river, or in the counties in the central part of the state touched by the Erie Canal, such as Oneida.

\subsection{Ownership}

For 132 of the 282 operating corporations, the complete list of their shareholders was found for at least one year, and for 246, the geographical distribution of their shares aggregated by county

\footnotetext{
${ }^{33}$ The comptroller's records include many firms that filed reports in 1826 and not 1827, and vice versa. Although in a few of the former cases it is clear that the firms went bankrupt in 1826, in most such cases the comptroller's office did not know the reason for the missing report. Therefore all companies that filed in either year are included.
} 
Table 2:

New York Business Corporations in Operation in 1826 or 1827: Industrial Composition, Location, and Paid-In Captial

Firms determined by the New York comptroller to have been in operation in 1826 or 1827, and their paid-in capital, by industry and by county. Total charters granted is the number of charters granted in New York from 1790-1825. The percentage of firms in operation is the number of firms in operation divided by the number of charters granted. Hudson River Valley Counties includes Albany, Rensselaer, Greene, Columbia, Ulster, Dutchess, Orange, Putnam, Rockland, and Westchester.

\begin{tabular}{|c|c|c|c|c|c|}
\hline & \multirow{3}{*}{$\begin{array}{c}\text { Total } \\
\text { Charters } \\
\text { Granted }\end{array}$} & \multirow{3}{*}{$\begin{array}{c}\text { Total } \\
\text { Operating } \\
\text { Firms }\end{array}$} & \multirow{3}{*}{$\begin{array}{c}\% \text { of } \\
\text { Firms in } \\
\text { Operation }\end{array}$} & \multicolumn{2}{|c|}{ Operating firms: } \\
\hline & & & & Avg. & Total \\
\hline & & & & Capital & Capital \\
\hline All Firms & 812 & 282 & .35 & 169,687 & $47,851,576$ \\
\hline \multicolumn{6}{|l|}{ Industrial Composition } \\
\hline Banks & 43 & 41 & .95 & 505,835 & $20,739,240$ \\
\hline Bridge Companies & 86 & 36 & .42 & 11,480 & 413,288 \\
\hline Insurance \& Related Finance & 74 & 54 & .73 & 343,058 & $18,525,168$ \\
\hline Manufacturing Companies & 221 & 67 & .30 & 57,405 & $3,846,168$ \\
\hline Turnpikes & 304 & 63 & .21 & 34,187 & $2,173,924$ \\
\hline All Others & 84 & 21 & .25 & 103,520 & $2,153,790$ \\
\hline \multicolumn{6}{|l|}{ Location } \\
\hline New York City & 121 & 74 & .61 & 462,048 & $34,191,572$ \\
\hline Hudson River Valley Counties & 210 & 69 & .33 & 72,092 & $6,560,395$ \\
\hline Oneida County & 52 & 22 & .42 & 85,718 & $1,885,792$ \\
\hline Brooklyn (Kings County) & 12 & 9 & .75 & 73,778 & 664,000 \\
\hline All Other Counties & 417 & 114 & .27 & 52,905 & $4,549,818$ \\
\hline
\end{tabular}

was found. Most of the stockholder lists are for the year 1826, although a small handful are from other years. In that year, the equity of 63 firms was traded on the New York Stock and Exchange Board; all but one of these publicly-traded firms operated in New York City (with one in Brooklyn), and all but four were banks and insurance companies. ${ }^{34}$ This market almost certainly facilitated substantially greater diffusion of the shares of the listed companies.

Some summary statistics of these data are presented in table 3 . There was an enormous degree of variation in ownership structures across firms. The number of owners ranged from 560 (Bank of America, capital $\$ 2$ million) to just 3 (Athens Turnpike Company, capital $\$ 8,000$ ). On average, the corporations had about 74 shareholders, which implies that at least some small stakes were commonly held. The surnames of the shareholders reveal that kinship ties may have been important in the allocation of shares; for $26 \%$ of investors in each corporation, there was another investor in that corporation with the same surname. The average firm's equity was owned in 5 counties, with $34 \%$ owned in New York City, and 10\% owned outside of New York State. Certainly a fair number of shareholders lived far away from the businesses in which they invested, and very likely had no contact with or involvement in their day-to-day operations.

Looking across the different industries, those with the largest firms, such as banks and insurance,

\footnotetext{
${ }^{34}$ The remaining companies included two mining companies, a water company, and a gas light company.
} 
Table 3:

Ownership Structure: Industry Means

Means of measures of ownership structure for all operating firms where data could be obtained, by industry. The percentage of shareholders with a surname in common measures the percentage of shareholders for whom there is another shareholder in the same corporation with the same surname. Measures of cash flow rights are based on the distribution of the corporations' shares, but measures of the distribution of voting rights are calculated by applying the voting rights specified in the corporate charters to the distribution of shares.

\begin{tabular}{|c|c|c|c|c|c|c|c|}
\hline & $\begin{array}{c}\text { All } \\
\text { Firms }\end{array}$ & Banks & Bridges & $\begin{array}{l}\text { Insurance } \\
\text { \& Finance }\end{array}$ & $\begin{array}{c}\text { Manu- } \\
\text { facturing }\end{array}$ & Turnpikes & $\begin{array}{c}\text { All } \\
\text { Others }\end{array}$ \\
\hline \multicolumn{8}{|l|}{ Shareholders $(N=132)$} \\
\hline Total number of shareholders & 74 & 252 & 59 & 132 & 17 & 69 & 59 \\
\hline$\%$ of shareholders w/surname in common & .26 & .33 & .27 & .24 & .27 & .30 & .22 \\
\hline$\%$ held by other corporations & .04 & .15 & 0 & .07 & .01 & 0 & .08 \\
\hline \multicolumn{8}{|l|}{ Concentration of Ownership $(N=132)$} \\
\hline Cash flow rights & .48 & .61 & .49 & .46 & .42 & .54 & .55 \\
\hline Voting rights & .44 & .55 & .45 & .44 & .42 & .37 & .50 \\
\hline \multicolumn{8}{|l|}{ Gini coefficient } \\
\hline Cash flow rights & .57 & .71 & .55 & .59 & .47 & .62 & .67 \\
\hline Voting rights & .52 & .64 & .50 & .57 & .46 & .45 & .65 \\
\hline \multicolumn{8}{|l|}{ Geographical Distribution $(N=246)$} \\
\hline Number of counties in which stock held & 5 & 8 & 3 & 5 & 3 & 5 & 4 \\
\hline$\%$ of stock held in New York City & .34 & .37 & .08 & .76 & .23 & .12 & .44 \\
\hline$\%$ of stock held outside New York State & .10 & .16 & .08 & .10 & .07 & .09 & .08 \\
\hline
\end{tabular}

had the largest numbers of shareholders, and their ownership was also the most geographically dispersed. The wide ownership of banks and insurance companies was probably also due in part to the appeal of the equity of these often consistently-profitable firms to a broad range of investors, who could trade shares in these companies through brokers on the stock exchange in New York City. Moreover, firm size clearly was not the only determinant of ownership diffusion: manufacturing firms, which were on average much larger than either turnpike companies or bridge companies, had by far the smallest numbers of shareholders. Almost all of the manufacturing enterprises in the dataset could be considered "close corporations," with very illiquid shares that traded only rarely, held in large blocks by local investors. ${ }^{35}$

The table also includes two measures of the degree of concentration of ownership: the total fraction held by the top $10 \%$ of investors, and also the Gini coefficient of shareholdings. These measures are presented both for cash flow rights (percentage of the shares held) and voting rights, calculated from the entire distribution of shareholdings according to the voting configuration specified in the charter. On average, most firms had a few very large shareholders, with the top $10 \%$ holding $48 \%$ of the shares. The firms with the most equally distributed shares were in manufacturing, and

\footnotetext{
${ }^{35}$ The surviving stock ledgers of manufacturing companies record relatively few transactions. For example, the Whitestown Cotton and Wollen Manufacturing Company had 15 shareholders in the mid-1820s, and from the inception of the firm in 1812 until the end of the ledger in 1827, a total of 34 people held shares at some time. Many of the transfers that did occur were between family members (Stock Ledger, Oneida County Historical Society, Utica NY.)
} 
the most unequally distributed were in banking, turnpikes, and some of the firms included in the "other" category. The effect of the voting rights configurations chosen in the different industries on the power of large shareholders can be seen by comparing the measures of inequality in cash flow rights with those of voting rights. In nearly all industries except manufacturing, where one vote per share was nearly always chosen, the voting rights of large shareholders was curtailed at least somewhat. In particular, in banks and turnpikes, the voting rights configurations chosen reduced the power of large shareholders substantially. This finding implies that many investors were willing to hold stakes in firms well in excess of the voting rights they would be granted. Even if they did circumvent the effects of the firms' voting rights by holding shares in more than one name, they apparently did not do so enough to ensure that their voting power was undiminished.

\subsection{Managerial Ownership and Corporate Control}

A crucial element in understanding the ownership structure of these firms, and the extent of separation between ownership and control, is the degree of managerial ownership. Unfortunately, the lists of shareholders submitted pursuant to New York's capital tax did not identify the directors of the firms, and were simply signed by the corporate secretary or president. An extensive search of contemporary newspapers and city directories was therefore undertaken, and eventually the lists of directors for 51 of the corporations were obtained, and matched to a shareholder list. ${ }^{36}$ The corporations for which a directors list could be found through this approach were overwhelmingly located in New York City (43 of 51 firms), and tended to be institutions of a "public" character, such as insurance companies, banks, and large manufacturing companies. If the relationship between firm size and managerial ownership of the twentieth century holds for this period, then the extent of managerial ownership in the large firms for which directors lists could be found is probably close to a lower bound for overall managerial ownership. ${ }^{37}$

Moreover, unlike the proxy statements of modern public firms, where the shares "beneficially owned" or controlled by management are precisely enumerated, the shareholder lists from the 1820s do not identify shares that a director might have controlled or voted, but that he did not own directly. For example, some contemporary accounts mention the practice of shareholders

\footnotetext{
${ }^{36}$ Many corporations at the time listed their directors in advertisements or solicitations, and the results of elections of directors were sometimes reported in newspapers. These findings were supplemented with a few lists of directors obtained from the minute books of directors' meetings held in various archives. See the Data Appendix.

${ }^{37}$ The extent of managerial ownership, and the relationship between ownership and firm size, is documented in Holderness, Kroszner, and Sheehan (1999).
} 
"giving their proxies to officers of banks," or essentially delegating their votes to the management itself. ${ }^{38}$ There is no way to know how common such voting agreements were, as no such agreements were identified on the shareholder lists. Similarly, some corporations, particularly insurance firms, held relatively large stakes in other corporations, and it was often the case that a director of the insurance firm was also a director of the corporation in which the insurance firm held a stake. In compiling the directors' shareholdings, I assumed that the shares owned by any corporations in which a shareholder was a director would be voted by that shareholder.

Often the lists of stockholders included trusts, where one or more of the directors were trustees. Consistent with the treatment of shares owned by corporations, and with contemporary accounts, I assumed that the directors would vote those shares. However, in many cases these shares were actually treasury shares or shares forfeited by investors who never paid in the amounts they subscribed for. In principle, these shares should not have entitled their trustees to any votes. And yet the contemporary case law indicates that the shares in such trusts, which often constituted large or even majority blocks of shares, were voted by the directors of the firm. ${ }^{39}$ Consider the example of the Tradesmen's Insurance Company. At its founding in 1825, a group of seven investors, one of whom was the president of a New Jersey bank, subscribed to a majority of the shares. This acquisition was financed through a "stock note" issued by the bank: the bank took the shares as collateral, and the company was given deposit credit at the bank equal to that amount. When some of the other bank directors objected to the transaction and refused to accept checks drawn by the Insurance Company on its account, the transaction was eventually reversed, and the shares were returned to the company. But rather than acknowledging that the shares had effectively never been paid in, the directors placed the shares in a trust, with the president of the company and two other directors as trustees. As the nominal owners of the stock, they voted the shares. ${ }^{40}$ And because the shares in the trust accounted for 1,582 of the company's 4,000 total shares, the votes of these shares, when added to those of the shares owned directly by the board (511), gave them $52 \%$ of the votes of the firm (the firm's charter specified that each share was entitled to one vote). In most cases, however, it is not possible to observe whether the directors actually voted those shares,

\footnotetext{
${ }^{38}$ New York Daily Advertiser, 4 June 1819.

${ }^{39}$ In some cases the shares were not held within a trust, but were instead held in the name of the president of the company, or the company itself. For example, the 1826 stockholder list for the United States Fire Insurance Company lists John L. Bowne, its president, as the owner of 189 shares, but then also lists "John L. Bowne, President" as owner of 966 shares. (New York State Archives, Albany NY.)

${ }^{40}$ These votes were later held to be illegal (Ex parte Holmes 5 Cow 426 New York (Sup Ct 1826)), but this practice seems not to have been unusual.
} 


\section{Table 4:}

\section{Managerial Voting Rights: Industry Means}

Means of measures of managerial ownership for all operating firms where data could be obtained, by industry. The total number of firms for which data on managerial ownership could be obtained was 51. Total managerial cash flow rights includes shares held directly and indirectly by the members of the board. Shares held indirectly includes shares held in trust, shares held by another corporation in which a board member is also a director, shares held by a partnership in which a director is a member, and shares held in the name of the president of the company or the company itself. The voting stake of outside $5 \%$ blockholders is the total percentage of the votes to which all holders of $5 \%$ or more of the shares who are not on the board are entitled, given the voting rights specified in the charter. The margin of managerial control is the difference between the voting rights of management, and the voting stake of outside $5 \%$ blockholders.

\begin{tabular}{|c|c|c|c|c|c|c|}
\hline & $\begin{array}{c}\text { All } \\
\text { Firms }\end{array}$ & Banks & $\begin{array}{c}\text { Insurance \& } \\
\text { Finance }\end{array}$ & $\begin{array}{c}\text { Manu- } \\
\text { facturing }\end{array}$ & Turnpikes & $\begin{array}{c}\text { All } \\
\text { Others }\end{array}$ \\
\hline Total managerial cash flow rights & .42 & .20 & .39 & .64 & .28 & .47 \\
\hline Shares held directly & .28 & .11 & .22 & 63 & .27 & .21 \\
\hline Shares held indirectly & .14 & .08 & .17 & .01 & .01 & .26 \\
\hline Total managerial voting rights & .39 & .18 & .38 & .57 & .19 & .40 \\
\hline Voting stake of outside $5 \%$ blockholders & .07 & .09 & .04 & .21 & .05 & .02 \\
\hline Margin of managerial control & .32 & .10 & .34 & .36 & .14 & .38 \\
\hline
\end{tabular}

so there is a danger that the managerial ownership data presented below may overstate the stake held by the directors somewhat, if they in fact did not vote shares held in this way.

With these caveats in mind, the data for managerial ownership are presented in table 4 . The data indicate that on average, ownership by the directors was extremely high, with $28 \%$ of the shares held directly, and 14\% held indirectly, either through corporations, partnerships or trusts, for a total ownership stake of $42 \%$. Given the firms' voting rights configurations, these stakes entitled the directors on average to $39 \%$ of the total votes of their firms. Compared to mean ownership of about $13 \%$ and $21 \%$ for American public corporations in 1935 and 1995, respectively (Holderness, Kroszner, and Sheehan, 1999), the extent of managerial shareholding in the 1820s was much higher. The levels of management ownership during the period are similar to those of modern firms in the first year after their IPO, which is about 38\% (Helwege, Pirinsky, and Stulz, 2007).

In order to assess the relative power of management's voting stake, the percentage of all of the votes controlled by holders of $5 \%$ or more of the stock who were not on the board was also calculated. As these large blockholders had the greatest incentive to monitor the performance of management, and to vote their shares, they were the mostly likely check on management's power. On average, these blockholders controlled $7 \%$ of the firms' votes, meaning that the margin of managerial control was $32 \%$. Many of the firms might have been characterized by Berle and Means as under minority control, as the stake held by insiders was large enough to be unchecked by any outside investors.

The data presented in table 4 also indicate that there was substantial variation across industries 
in the degree of managerial ownership in the firms. The directors of manufacturing firms held enormous stakes, with $64 \%$ of the shares in total, but as the ownership of the shares was evenly distributed among a small number of shareholders, many of the investors not on the board also held large stakes, and the total votes of outside blockholders was $21 \%$. In these firms, many of which could be characterized as controlled by almost complete ownership, there was barely any separation of ownership from control. In contrast, the management of turnpikes and banks held much smaller stakes, and were entitled to around $20 \%$ of their firms' votes. The directors of insurance firms held $39 \%$ of their firm's shares, and nearly half of that was due to shares held indirectly, either through corporations (usually other insurance firms) or shares held in trusts.

Although one might be tempted to interpret the high degree of insider ownership as consistent with strong managerial incentives, and perhaps good governance, it is likely that the opposite was true. Directors in early-nineteenth-century corporations held sweeping powers to utilize their firms' resources for their own benefit and engage in self-dealing; bank directors, for example, were commonly the largest borrowers from their own firms. ${ }^{41}$ The comfortable margin control over the firms' votes held by insiders implies that these firms were operated by managers who were not accountable to outside shareholders, and also had the authority to utilize their firms' resources for their own benefit.

The next section of the paper analyzes the connection between the governance provisions selected in the corporate charters, and the ownership and control of the firms.

\section{Ownership and Governance: Empirical Analysis}

Which configuration of voting rights was chosen for firms with small shareholders? And perhaps more importantly, what was the effect of different voting rights on the extent of control of the corporations by large shareholders or directors? By examining the variation in the ownership structures and voting rights configurations both between and within industries, the nature of the relationship between the two can be better understood.

Looking across industries presents some striking contrasts. For example, if we compare the manufacturing firms to the banks and turnpike companies, clear differences in their ownership and governance "styles" emerge. Manufacturing firms had relatively few shareholders, the most equally

\footnotetext{
${ }^{41}$ On insider lending by banks, see Lamoreaux (1994). Rules governing self-dealing by directors first appeared in New York's revised statues of 1829, which limited total loans to directors to one third of a firm's paid-in capital (Revised Statutes, Title 2, Article 1.)
} 
distributed ownership, and the greatest degree of managerial ownership. They essentially had no small investors, and did not bother with the requirements of producing accounting statements or mandatory dividend payments, or with graduated voting rights schemes. The shares were owned in large blocks, and each investor had a strong incentive to monitor the performance of the firm.

In contrast, banks and turnpike companies had much larger numbers of shareholders, the most unequally distributed ownership, and the lowest degree of managerial ownership. Firms in these industries often utilized graduated voting rights schemes, probably in an effort to offer small shareholders some protection from the power of large shareholders. And they had larger boards, perhaps as a means to increase the representation of different interests in the governance of the firm.

The other major industries in the dataset, bridge companies and insurance companies, lie somewhere in between the extremes represented by manufacturing companies, on the one hand, and banks and turnpikes, on the other. Their degree of ownership concentration and numbers of stockholders were certainly within the middle range of that spectrum.

These comparisons across industries suggest the the degree of ownership concentration was negatively related to the voting rights index chosen: firms in industries with unequally-distributed shares tended to configure their voting rights in a way that diminished the power of large investors. One might imagine that these firms would also offer other governance provisions designed to better represent or protect small investors as well. But as this regularity observed between industries might be due to other industry characteristics, a more persuasive test of this relationship would focus on the within-industry variation in these measures. The ownership structure and governance institutions of the firms, of course, were jointly endogenous, so the results presented below should be interpreted as a descriptive analysis of the correlations in the data, rather than identification of a causal relationship. But within-industry comparisons nonetheless shed important light on the nature of the relationship between ownership structures and governance institutions.

Therefore, I analyze these relationships in the context of a regression framework, which includes firm characteristics as controls, as well as industry fixed effects. The number of years a firm had existed would likely influence its ownership: over time, one might expect that the founders of the firm, and other early investors, would gradually sell shares to new investors. ${ }^{42}$ Certainly the size of firms might affect these measures as well. Therefore, in what follows, I regress measures of ownership structures on measures of governance provisions, and firm size and age. Specifically, for

\footnotetext{
${ }^{42}$ Field and Hanka (2001), for example, document this phenomenon among the managers of modern firms that go public.
} 


\section{Table 5:}

\section{Regressions: Firm Ownership Structures}

Regressions of charter governance provisions on measures of the distribution of ownership. All specifications include fixed effects for industries. Although 132 shareholder lists have been found, for 6 of these firms, the charter was silent on the voting rights of stockholders, so only 126 observations could be included in the regressions. The dependent variables in columns (1) through (5) are, respectively, the percentage of the firm's cash flow rights held by the top $10 \%$ of the shareholders, the percentage of the firm's votes held by the top $10 \%$ of the shareholders, the log of the total number of shareholders, the log of the total number of New York counties within which the firm's stock is owned, and the percentage of the shareholders for whom there is another shareholder in the same corporation with the same surname. Standard errors in parentheses; ***, **, and * denote significance at $1 \%, 5 \%$, and $10 \%$, respectively. A constant term (not reported) is also included.

\begin{tabular}{|c|c|c|c|c|c|}
\hline & $\begin{array}{c}(1) \\
\% \text { Held by the } \\
\text { Top } 10 \% \\
\text { (Mean .48; } \\
\text { SD .17) }\end{array}$ & $\begin{array}{c}\text { (2) } \\
\text { Voting share } \\
\text { of Top } 10 \% \\
\text { (Mean .44; } \\
\text { SD .18) } \\
\end{array}$ & $\begin{array}{c}(3) \\
\log (\text { Number of } \\
\text { Shareholders) } \\
\text { (Mean 3.65; } \\
\text { SD 1.24) }\end{array}$ & $\begin{array}{l}\text { (4) } \\
\log (\text { Number } \\
\text { of Counties) } \\
\text { (Mean 1.28; } \\
\text { SD .75) }\end{array}$ & $\begin{array}{l}(5) \\
\% \mathrm{w} / \text { name } \\
\text { in common } \\
\text { (Mean .26; } \\
\text { SD .18) }\end{array}$ \\
\hline Voting rights index $\left(V_{i}\right)$ & $\begin{array}{c}0.065 \\
(0.054)\end{array}$ & $\begin{array}{c}0.321^{* * *} \\
(0.046)\end{array}$ & $\begin{array}{c}-0.528^{* *} \\
(0.241)\end{array}$ & $\begin{array}{c}-0.278^{*} \\
(0.147)\end{array}$ & $\begin{array}{c}-0.078^{* *} \\
(0.038)\end{array}$ \\
\hline Mandatory dividend & $\begin{array}{c}0.124 \\
(0.135)\end{array}$ & $\begin{array}{c}0.148 \\
(0.136)\end{array}$ & $\begin{array}{l}-0.028 \\
(0.247)\end{array}$ & $\begin{array}{l}-0.139 \\
(0.178)\end{array}$ & $\begin{array}{l}-0.056 \\
(0.052)\end{array}$ \\
\hline Annual financial statements & $\begin{array}{c}0.037 \\
(0.042)\end{array}$ & $\begin{array}{c}0.038 \\
(0.043)\end{array}$ & $\begin{array}{c}0.015 \\
(0.165)\end{array}$ & $\begin{array}{l}-0.118 \\
(0.119)\end{array}$ & $\begin{array}{l}-0.009 \\
(0.044)\end{array}$ \\
\hline Number on board & $\begin{array}{c}-0.004^{* * *} \\
(0.001)\end{array}$ & $\begin{array}{c}-0.004^{* * *} \\
(0.001)\end{array}$ & $\begin{array}{c}0.026^{* *} \\
(0.012)\end{array}$ & $\begin{array}{c}0.013^{* * *} \\
(0.004)\end{array}$ & $\begin{array}{l}-0.000 \\
(0.001)\end{array}$ \\
\hline $\log$ (paid-in capital) & $\begin{array}{l}-0.005 \\
(0.016)\end{array}$ & $\begin{array}{l}-0.014 \\
(0.014)\end{array}$ & $\begin{array}{c}0.113 \\
(0.093)\end{array}$ & $\begin{array}{c}0.192^{* * *} \\
(0.040)\end{array}$ & $\begin{array}{c}0.019 \\
(0.020)\end{array}$ \\
\hline $\log$ (firm age) & $\begin{array}{l}-0.011 \\
(0.018)\end{array}$ & $\begin{array}{l}-0.013 \\
(0.017)\end{array}$ & $\begin{array}{c}0.086 \\
(0.082)\end{array}$ & $\begin{array}{c}0.171^{* * *} \\
(0.046)\end{array}$ & $\begin{array}{l}-0.000 \\
(0.021)\end{array}$ \\
\hline Industry Effects & $\mathrm{Y}$ & $\mathrm{Y}$ & $\mathrm{Y}$ & $\mathrm{Y}$ & $\mathrm{Y}$ \\
\hline $\mathrm{R}^{2}$ & 0.15 & 0.26 & 0.65 & 0.46 & 0.06 \\
\hline Observations & 126 & 126 & 126 & 233 & 126 \\
\hline
\end{tabular}

firm $i$, I estimate the determinants of ownership measure $s_{i}$ as

$$
s_{i}=\gamma_{0}+\gamma_{1} \mathrm{~V}_{i}+\mathbf{x}_{i} \beta+\sum_{k} \phi_{k} \text { industry }_{i k}+u_{i},
$$

where $\mathrm{V}_{i}$ is the voting rights index; $\mathbf{x}_{i}$ is a vector of firm characteristics, including other governance provisions; and the industry ${ }_{i k}$ terms are a series of six indicator variables for each industry in the sample. A table of summary statistics for all the variable included in the regressions is included in the data appendix.

The results for the ownership stakes and voting power of large shareholders, and measures of the diffusion of ownership, are presented in table 5. In column (1), the degree of concentration of ownership, measured by the percentage of the shares held by the top $10 \%$ of the investors, is the dependent variable. Although the comparisons between industries suggest that ownership concentration should be negatively correlated with the voting rights index, the results of this regression 
indicate that there was no within-industry relationship between voting rights and ownership concentration. This also at least suggests that graduated voting rights schemes did not cause the distribution of shares to become more equal, and also that they did not cause widespread efforts by large shareholders to circumvent these schemes by holding shares in multiple names. Evidently, investors were willing to hold stakes that were large enough to be penalized by graduated voting rights schemes.

The results in column (2), where the voting rights (as opposed to ownership stakes) of the top $10 \%$ of shareholders is the dependent variable, therefore follow immediately: firms that selected voting rights schemes schemes that limited the power of large investors imposed them on essentially the same distribution of ownership, resulting in much lower voting rights for the largest shareholders. The regressions in columns (3) and (4) investigate whether lower values of the voting rights index were associated with more diffuse ownership, either in the form of a larger number of owners, or in a wider geographical distribution of the shares. In both cases, the variation in the voting rights index within industries does seem to be associated with somewhat greater diffusion; a one-standarddeviation increase in the voting rights index was associated with a reduction equivalent to about $15 \%$ of a standard deviation in both the log of the number of owners, and the log of the number of counties in which the shares were held. Note that this is consistent with small, potentially more distant shareholders expressing a preference for investments in firms with lower values of the voting rights index, but it is also consistent with shareholders holding their stakes in multiple names when graduated voting rights were chosen. Somewhat clearer evidence of the latter is found in column (5), where the dependent variable is the percentage of the shareholders whose surname is the same as that of another shareholder. If investors tried to circumvent graduated voting rights schemes by holding their stakes in the names of others, it would have been convenient to hold them in the names of relatives. And indeed this seems to have been the case, although the effect is extremely small: the parameter estimates indicate that a one-standard-deviation increase in the voting rights index was associated with a decrease equal to $3 \%$ of a standard deviation of the degree of commonality of the shareholders' surnames.

Interestingly, in each of the regressions for the degree of diffusion of ownership, there is a robust association between the number of members of the board, and the degree of diffusion. Evidently larger boards were specified for firms with greater numbers of investors, and less concentrated ownership. But perhaps in an indication of the low quality of financial reporting at the time, there 
Table 6:

Regressions: Managerial Ownership and Control

Regressions of charter governance provisions on measures of extent of managerial control. All specifications include fixed effects for industries. The dependent variables in columns (1) through (4) are, respectively, the percentage of the firm's cash flow rights held by the board (both directly and indirectly), the percentage of the firm's votes held by the board (both directly and indirectly), the percentage of the votes controlled by holders of at least $5 \%$ of the shares who are not on the board, and the difference between the voting rights of management, and the voting stake of outside $5 \%$ blockholders. Firm age is measured as the number of years since the firm received its charter. Standard errors in parentheses; ***, **, and * denote significance at $1 \%, 5 \%$, and $10 \%$, respectively. A constant term (not reported) is also included.

\begin{tabular}{|c|c|c|c|c|}
\hline & $\begin{array}{c}\text { (1) } \\
\% \text { Held by } \\
\text { Board } \\
\text { (Mean .42; SD .24) } \\
\end{array}$ & $\begin{array}{c}(2) \\
\text { Voting share } \\
\text { of Board } \\
\text { (Mean .39; SD .24) }\end{array}$ & $\begin{array}{c}(3) \\
\text { Voting Share of } \\
\text { Outside Blockholders } \\
\text { (Mean .07; SD .10) }\end{array}$ & $\begin{array}{c}(4) \\
\text { Margin of } \\
\text { Board Control } \\
\text { (Mean .33; SD .25) }\end{array}$ \\
\hline Voting rights index $\left(V_{i}\right)$ & $\begin{array}{c}0.182^{* *} \\
(0.081)\end{array}$ & $\begin{array}{c}0.286^{* * *} \\
(0.079)\end{array}$ & $\begin{array}{l}0.053^{*} \\
(0.028)\end{array}$ & $\begin{array}{c}0.232^{* *} \\
(0.090)\end{array}$ \\
\hline Annual financial statements & $\begin{array}{c}0.014 \\
(0.076)\end{array}$ & $\begin{array}{c}0.043 \\
(0.077)\end{array}$ & $\begin{array}{l}-0.029 \\
(0.029)\end{array}$ & $\begin{array}{c}0.072 \\
(0.089)\end{array}$ \\
\hline Number on board & $\begin{array}{l}-0.002 \\
(0.002)\end{array}$ & $\begin{array}{l}-0.002 \\
(0.002)\end{array}$ & $\begin{array}{c}-0.001 \\
(0.000)\end{array}$ & $\begin{array}{c}-0.001 \\
(0.002)\end{array}$ \\
\hline $\log ($ capital $)$ & $\begin{array}{c}-0.068 \\
(0.068)\end{array}$ & $\begin{array}{c}-0.052 \\
(0.067)\end{array}$ & $\begin{array}{c}-0.049 * * \\
(0.022)\end{array}$ & $\begin{array}{c}-0.003 \\
(0.076)\end{array}$ \\
\hline $\log$ (firm age) & $\begin{array}{c}-0.032 \\
(0.042)\end{array}$ & $\begin{array}{c}-0.014 \\
(0.042)\end{array}$ & $\begin{array}{c}0.007 \\
(0.016)\end{array}$ & $\begin{array}{c}-0.021 \\
(0.049)\end{array}$ \\
\hline Industry Effects & $\mathrm{Y}$ & $\mathrm{Y}$ & $\mathrm{Y}$ & $\mathrm{Y}$ \\
\hline $\mathrm{R}^{2}$ & 0.34 & 0.33 & 0.50 & 0.20 \\
\hline Observations & 51 & 51 & 51 & 51 \\
\hline
\end{tabular}

was no correlation between requirements to produce financial statements annually, and the degree of ownership diffusion.

Results for regressions estimating the relationship between governance provisions and managerial ownership are presented in table 6. The sample used in these regressions is considerably smaller, and in the remaining observations there is no within-industry variation in the use of dividend requirements, so that regressor is dropped. The estimates tell a slightly different story than those in table 5: higher values of the voting rights index were associated with greater degrees of managerial ownership, and amplified the voting power of their larger stakes. Although outside $5 \%$ blockholders also had a larger share of the votes, the margin of managerial control was much higher for firms with higher levels of the index. Thus, even though the overall degree of ownership concentration did not vary with the voting rights chosen, the degree of managerial ownership and control did, and strongly: a one-standard-deviation increase in the voting rights index was associated with an increase in managerial voting power of about $45 \%$ of a standard deviation. 


\section{Empirical Analysis: Firm Values}

Assessing the impact of the ownership and governance data presented above for small investors or for the performance of the firms is difficult. It is likely that the management and/or large blockholders of some of the corporations in the dataset were essentially unaccountable to the other investors, and the governance institutions specified in the charters of these enterprises played some part in determining the extent of the balance of power between insiders and outsiders. But ultimately the question of interest is: how did this balance of power affect the performance of the firms? The absence of any financial reports or accounting data for most of the firms certainly presents challenges for any attempt to address this question.

One avenue for investigation that is available is to analyze the market values of the publiclytraded corporations within the sample. In 1826, the year of most of the shareholder lists in the dataset, the shares of about 63 New York corporations were traded with some regularity on the New York Stock and Exchange Board (NYS\&EB). ${ }^{43}$ These were all shares of common stock, and although newspapers did not report trading volumes until around 1828, contemporary accounts suggest that the market for many corporate securities was quite liquid. ${ }^{44}$ Thus the reported price data of these markets might reasonably be interpreted as informative of the market's assessments of the firms. Weekly prices of all equities that traded regularly on the NYS\&EB were recorded from contemporary newspapers by Sylla, Wilson and Wright (2005), and these data were matched to the companies in the dataset.

The NYS\&EB price data present at least two challenges for the researcher attempting to use them in this way. First, although most modern research on firm value uses measures of Tobin's Q as the focus of the analysis (eg, Morck, Shleifer, Vishny, 1988; Gompers, Ishii, Metrick, 2003), the NYS\&EB data can not be used to construct a measure of $Q$, as there is no data available on the value of the firms' liabilities. The prices quoted in transactions and reported in the press are expressed as a percentage of par value, or what would have been considered the book value of the

\footnotetext{
${ }^{43}$ From time to time, a transaction involving the shares of other, more obscure New York companies' equity were reported in the papers, but these were extremely rare and do not appear in the Sylla, Wilson and Wright (2005) dataset. In addition, the shares of a handful of corporations from other states, especially New Jersey, were traded regularly on the NS\&EB, as was the stock of the Second Bank of the United States, and many bond issues of the state, local, and federal governments.

${ }^{44}$ On the issuance of preferred stock by railroads in the 1840 s, see Evans (1929). NYS\&EB trading volumes were first reported in the New York Journal of Commerce in 1828; prior to that date many prominent New York papers reported prices but not volumes. On the history of the New York Stock Exchange and for early trading volume data, see Werner and Smith (1991).
} 
Figure 2:

Share Price Data, Four Stocks

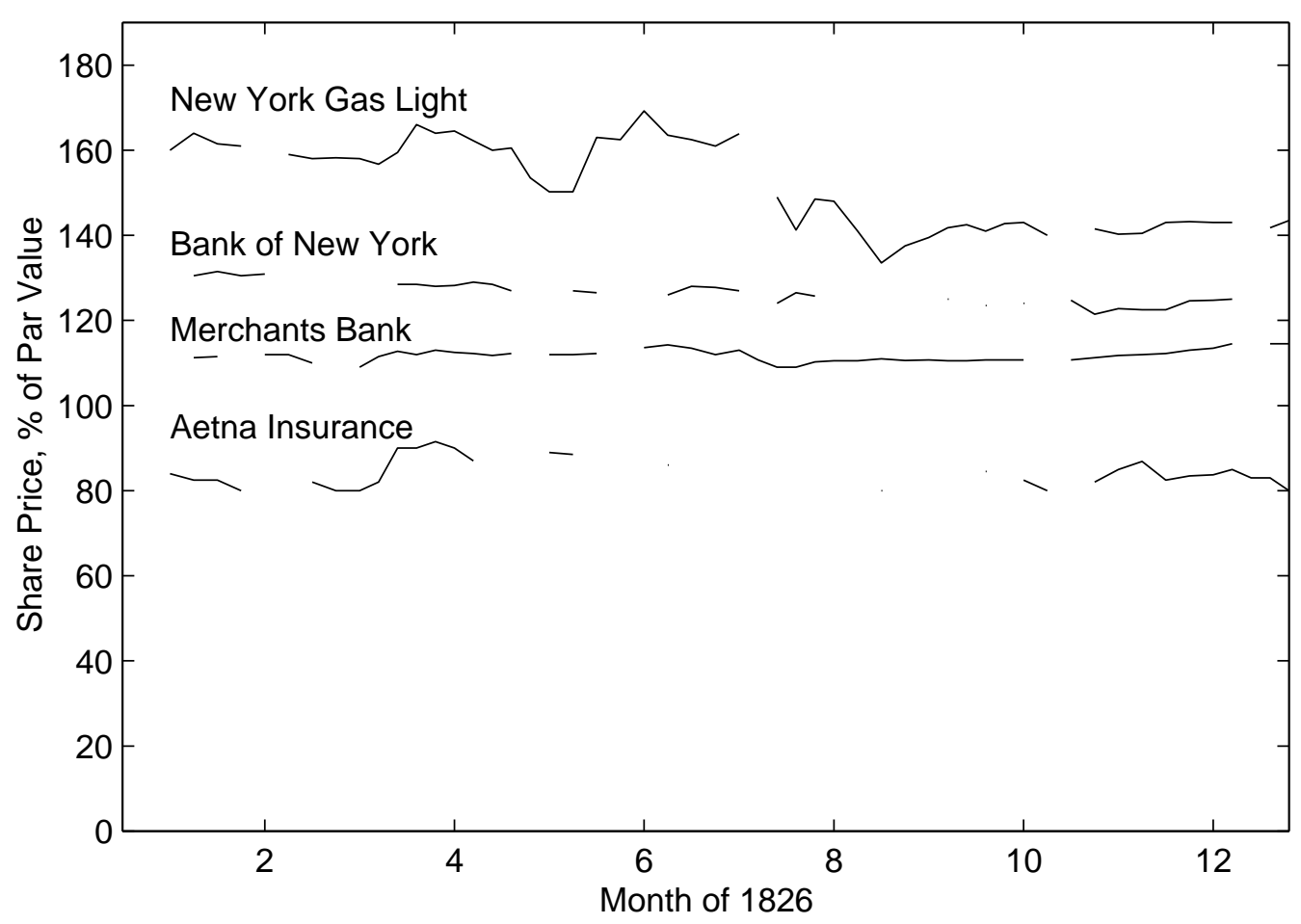

shares. ${ }^{45}$ Thus the data can be interpreted as an approximate measure of the ratio of the market value of equity to the book value of equity.

Secondly, many shares traded infrequently. Figure 2 presents a time series plot of the prices of four stocks of varying degrees of liquidity. Whereas for Merchants Bank and the New York Gas Light Company, transactions are recorded in most weeks, for the Bank of New York, and to a much greater extent for Aetna Insurance, there are many weeks or even entire months when the shares did not trade. Nevertheless, there are distinct differences in the average value of these firms over the course of the year, and the empirical analysis that follows will use the annual average values calculated from the weeks where transactions were recorded. ${ }^{46}$ But to address the problem that some firms may have recorded transactions only in particular months of more buoyant (or perhaps more depressed) conditions in the market, the analysis will include indicator variables for

\footnotetext{
${ }^{45}$ At the time, the accounting treatment of par value was that it was equal to what would now be called contributed capital; a firm's "capital stock" was equal to the par value of its shares multiplied by the number of shares. Any retained earnings were considered liabilities, so this notion of the capital stock was considered the book value of the firm's equity.

${ }^{46}$ The relative stability of the firms' values over time is consistent with the the model of Jin and Myers (2006), which finds that in opaque firms with poor corporate governance and weak investor protections, insiders may absorb firm-specific risks through their efforts to capture part of the value of the firm. In their model insiders become the residual claimants, and the stock held by outsiders becomes more like preferred shares.
} 
Table 7:

Regressions: Ownership, Governance and Firm Value

Regressions of measures of governance and managerial control on firm value. The dependent variable is the mean ratio of market value to book value for the year of 1826 (Mean 88.7; SD 24.5), computed from weekly price data. As some firms did not trade during some months of 1826, indicator variables for each month in the year within which the firm's shares traded are included in the regressions, to control for market conditions. All specifications include fixed effects for industries. Standard errors in parentheses; $* * *, * *$, and $*$ denote significance at $1 \%, 5 \%$, and $10 \%$, respectively. A constant term (not reported) is also included.

\begin{tabular}{|c|c|c|c|c|}
\hline & $(1)$ & $(2)$ & $(3)$ & $(4)$ \\
\hline Voting rights index $\left(V_{i}\right)$ & $\begin{array}{c}-17.624^{* *} \\
(8.350)\end{array}$ & & & \\
\hline Voting share of top $10 \%$ & & $\begin{array}{l}-48.163 \\
(30.836)\end{array}$ & & \\
\hline Voting share of management & & & $\begin{array}{c}-67.955^{* *} \\
(28.308)\end{array}$ & \\
\hline Margin of managerial control & & & & $\begin{array}{c}-64.417^{* *} \\
(26.230)\end{array}$ \\
\hline $\log ($ paid-in capital) & $\begin{array}{c}-5.975 \\
(7.028)\end{array}$ & $\begin{array}{c}-8.514 \\
(13.924)\end{array}$ & $\begin{array}{c}1.681 \\
(11.475)\end{array}$ & $\begin{array}{c}4.523 \\
(11.563)\end{array}$ \\
\hline $\log ($ firm age $)$ & $\begin{array}{c}8.105^{* *} \\
(3.241)\end{array}$ & $\begin{array}{c}11.906^{*} \\
(6.335)\end{array}$ & $\begin{array}{c}0.479 \\
(6.529)\end{array}$ & $\begin{array}{c}0.117 \\
(6.777)\end{array}$ \\
\hline Industry Effects & $\mathrm{Y}$ & $\mathrm{Y}$ & $\mathrm{Y}$ & $\mathrm{Y}$ \\
\hline Indicators for Months of Price Data & Y & $\mathrm{Y}$ & $\mathrm{Y}$ & $\mathrm{Y}$ \\
\hline $\mathrm{R}^{2}$ & 0.40 & 0.49 & 0.68 & 0.69 \\
\hline Observations & 62 & 41 & 37 & 37 \\
\hline
\end{tabular}

the months of the year in which transactions were recorded.

The relationship between the firms' values, and their governance provisions, is analyzed in a simple framework that focuses on the within-industry variation. Regressions of the following form will be estimated:

$$
\overline{M B}_{i}=\alpha_{0}+\alpha_{1} \mathrm{~V}_{i}+\mathbf{x}_{i} \beta+\sum_{j} \delta_{j} \operatorname{month}_{i j}+\sum_{k} \phi_{k} \text { industry }_{i k}+u_{i}
$$

where $\overline{M B}_{i}$ is firm $i$ 's average market-to-book ratio for $1826 ; \mathrm{V}_{i}$ is the index of the firm's voting rights; $\mathbf{x}_{i}$ includes firm characteristics such as the size of its capital stock, and its age; the month $_{i j}$ terms are a series of 12 indicator variables equal to 1 for each month of the year in which there was at least one transaction recorded for the firm's stock; and the industry ${ }_{i k}$ terms are a series of 6 indicators for the firms' industries. In subsequent specifications measures of ownership will be substituted for the voting rights index in the regression.

The results are presented in table 7 . Although the sample size is extremely small, and becomes smaller when the ownership variables are included in the regression, some clear patterns emerge. First, as shown in column (1), firms that offered voting rights that limited the voting power of 
large shareholders had higher values, compared to other firms in the same industry. The size of the coefficient indicates that a one-standard-deviation increase in the voting rights index would reduce the firm's market-to-book value by $25 \%$ of a standard deviation. The reason for this simple reduced-form relationship is suggested in columns (2)-(4), where ownership data are included in the regression. Each of the measures is negatively related to firm value, and in particular the ownership stake of management has a strongly negative relationship with firm value. This is consistent with insiders wielding control of their corporations for their own purposes and expropriating outsiders, and reducing the value of their firms. However, it may also be due to the market's perceptions of the quality of firms' capital: if investors knew that the capital stock was paid in using stock notes or other illiquid or risky financial instruments, this would have been reflected in the firms' valuations. If high levels of insider ownership or high levels of the voting index were negatively correlated with the quality of contributed capital, then this could also produce the same correlations.

\section{Discussion and Conclusion}

The business corporation found widespread adoption in the first three decades of the nineteenth century, as firms in a range of industries received corporate charters. This paper has used data from New York's capital tax of the 1820s to analyze the ownership and governance of many of these early firms.

One immediate conclusion that can be drawn from the results of this paper is that well before the emergence of the large industrial enterprises with tens of thousands of shareholders described by Berle and Means, ownership and control were quite commonly separated. In the 1820s, corporations were much smaller, and had far fewer shareholders, than the firms of the late-nineteenth century, but they suffered from this problem nonetheless. The extent of separation of ownership from control varied significantly across industries, and moreover what Berle and Means would call "managerial control," where ownership is so diffuse that professional, salaried managers effectively hold unchecked power, was probably quite uncommon. But "minority control," where firms were operated by managers holding stakes that were large enough to make them unaccountable to the other shareholders, was quite common. And many of the governance institutions of the firms at the time were configured to help mitigate this problem.

Early-nineteenth-century firms utilized a variety of means to offer protections to their investors and make their stock more attractive to small shareholders. Some specified graduated voting rights 
in their charters - configurations of voting rights where the number of votes a stockholder was entitled to decreased with the number of shares he owned. In response to an effectively punitive voting rights structure, in which the voting power of large blockholdings was strongly reduced, large investors did not, apparently, reconfigure their shareholdings to a large extent, but held stakes with severely diminished voting power. Evidently the gains attained from the protections offered to small shareholders outweighed the costs. Such voting rights schemes were associated with lower managerial ownership, and higher firm values.

Another conclusion that follows from the results of this paper is that the early evolution of the corporation was not a single process, but several processes occurring in parallel. Banks and insurance companies, for example, attracted large amounts of capital from a broad and diffuse base of investors, and their governance institutions were configured to facilitate this arrangement. Manufacturing firms, on the other hand, were quite closely held, with a few local investors holding large stakes, and effectively had no "small investors" at all. Over the course of the nineteenth century, with the rise of mass production, more integrated national markets, and other developments, manufacturing firms grew considerably in scale, and their ownership and governance evolved as well, whereas banks and other financial corporations continued to be subject to strict limits on their size and on the scope of their activities (see Roe, 1994).

Finally, the results of this paper suggest some important questions to be investigated in later periods, as the corporation continued to evolve. For example, the extent of managerial ownership of 1820 s corporations was extremely high by modern standards. At what point did managerial ownership begin to fall, and what developments were responsible for this change? Similarly, the United States is often described as having some of the best investor protections of any country in the world, and the least concentrated corporate ownership as a result. Certainly the level of investor protections offered in the early-nineteenth century were much weaker-but how these protections evolved across states and over time is far from clear. Answers to such questions will help place the findings of this paper in their historical context. 


\section{Bibliography}

Albany \& Schenectady Turnpike Road Company. 1801-22. Manuscript directors' minutes. NewYork Historical Society, New York NY.

Albion, Robert G. 1939. The Rise of New York Port. New York: Scribner's Sons.

Angell, Joseph K., and Samuel Ames. 1832. A Treatise on the Law of Private Corporations Aggregate. Boston: Hilliard, Gray, Little \& Wilkins.

Bank of America. 1812-24. Manuscript directors' minutes and correspondence. Citigroup Archives, New York NY.

Becht, Marco, and J. Bradford DeLong. 2005. "Why Has There Been So Little Block Holding in America?" in Randall K. Morck, ed., A History of Corporate Governance Around The World. Chicago: University of Chicago Press.

Berle, Adolf, and Gardiner Means. 1932. The Modern Corporation and Private Property. New York: Macmillan.

Bebchuk, Lucian A., and Alma Cohen. 2005. "The Costs of Entrenched Boards," Journal of Financial Economics, 78, 409-33.

Bebchuck, Lucian A., Kraakman, Renier, and George G. Triantis. "Stock Pyramids, CrossOwnership, and Dual Class Equity: The Mechanisms and Agency Costs of Separating Control from Cash-Flow Rights," in Mork, Randall K., ed., Concentrated Corporate Ownership. Chicago: University of Chicago Press.

Blandi, Joseph G. 1934. Maryland Business Corporations 1783-1852. Baltimore: J H Furst.

Bodenhorn, Howard. 2004. "Free Banking and Bank Entry in Nineteenth-Century New York," NBER Working Paper Series, no. 10654.

Bodenhorn, Howard. 2006. "Bank Chartering and Political Corruption in Antebellum New York: Free Banking as Reform," in Goldin and Glaeser, eds., Corruption and Reform: Lesson's from America's Economic History. Chicago: University of Chicago Press.

Cadman, John W. 1949. The Corporation in New Jersey: Business and Politics, 1781-1895. Cambridge: Harvard University Press.

Carlos, Ann M., and Larry Neal. "The Micro-Foundations of the Early London Capital Market: Bank of England Shareholders During and After the South Sea Bubble, 1720-25," Economic History Review, 59, 498-538.

Coffee, John C. 2001. "The Rise of Dispersed Ownership: The Roles of Law and the State in the Separation of Ownership and Control," Yale Law Journal, 111 (1), 1-82.

Davis, Joseph S. 1917. Essays in the Earlier History of Corporations. Cambridge: Harvard University Press.

Davis, Lance E. 1958. "Stock Ownership in the Early New England Textile Industry," Business History Review, 32, 204-222.

Dunlavy, Colleen A. 2004. "From Citizens to Plutocrats: 19th-Century Shareholder Voting Rights and Theories of the Corporation." In Constructing Corporate America: History, Politics, Culture, edited by Kenneth Lipartito and David B. Sicilia. Oxford: Oxford University Press, 66-93. 
Dodd, Edwin M. 1938. Lectures on the Growth of Corporate Structure in the United States with Special Reference to Governmental Regulation. Cleveland: Cleveland Bar Association.

1954. American Business Corporations Until 1860. Cambridge: Harvard University Press.

Evans, George H. 1929. "The Early History of Preferred Stock in the United States," American Economic Review, 19, 43-58.

. 1948. Business Incorporations in the United States, 1800-1943. New York: National Bureau of Economic Research.

Field, Laura C., and Gordon Hanka. 2001. "The Expiration of IPO Share Lockups," Journal of Finance, 56, 471-500.

Franks, Julian, Mayer, Colin, and Stefano Rossi. 2003. "The Origin and Evolution of Ownership and Control." Working Paper, European Corporate Governance Institute.

French, J. H. 1860. Gazetteer of the State of New York. Syracuse: R. Pearsall Smith.

Gillan, Stuart L., Hartzell, Jay C., and Laura T. Starks. 2006. "Tradeoffs in Corporate Governance: Evidence from Board Structures and Charter Provisions." Working paper, University of Texas.

Gompers, Paul, Ishii, Joy, and Andrew Metrick. 2003. "Corporate Governance and Equity Prices," Quarterly Journal of Economics, 118, 107-155.

Grossman, Sanford J., and Oliver D. Hart. 1988. "One Share-One Vote and the Market for Corporate Control," Journal of Financial Economics, 20, 175-202.

Hammond, Bray. 1957. Banks and Politics in America From the Revolution to the Civil War. Princeton: Princeton University Press.

Harris, Milton, and Artur Raviv. 1988. "Corporate Governance: Voting Rights and Majority Rules," Journal of Financial Economics, 20, 203-235.

Helwege, Jean, Pirinsky, Christo, and Rene M. Stulz. 2007. "Why Do Firms Become Widely Held? An Analysis of the Dynamics of Corporate Ownership," Journal of Finance, forthcoming.

Hilt, Eric. 2006. "Incentives in Corporations: Evidence from the American Whaling Industry," Journal of Law and Economics, 49, 197-227.

Holderness, Clifford G., Korszner, Randall S., and Dennis P. Sheehan. 1999. "Were the Good Old Days that Good? Changes in Managerial Stock Ownership Since the Great Depression," Journal of Finance, 54, 435-469.

Jensen, Michael, and William Meckling. 1976. "Theory of the Firm: Managerial Behavior, Agency Costs, and Ownership Structure," Journal of Financial Economics, 3, 305-360.

Jin, Li and Stewart Myers. 2006. " $R^{2}$ around the world: New theory and new tests," Journal of Financial Economics, 79, 257-292.

Kessler, William C. 1940. "A Statistical Study of the New York General Incorporation Act of 1811," Journal of Political Economy, 48, 877-82.

- 1948. "Incorporation in New England: A Statistical Study, 1800-1875," Journal of Economic History, 8, 43-62. 
Klein, Daniel B., and John Majewski. 1992. "Economy, Community and the Law: The Turnpike Movement in New York, 1797-1845," Law E Society Review, 26, 469-512.

Lamoreaux, Naomi. 1985. The Great Merger Movement in American Business, 1895-1904. New York: Cambridge University Press.

- 1994. Insider Lending: Banks, Personal Connections, and Economic Development in Industrial New England. New York: Cambridge University Press.

Lamoreaux, Naomi and Jean-Laurent Rosenthal. 2005. "Legal Regime and Business's Organizational Choice: A Comparison of France and the United States During the Era of Industrialization," American Law and Economics Review, 7, 28-61.

— and - 2006. "Corporate Governance and the Plight of Minority Shareholders in the United States Before the Great Depression," in Goldin and Glaeser, eds., Corruption and Reform: Lesson's from America's Economic History. Chicago: University of Chicago Press.

LaPorta, Rafael, Lopez-de-Silanes, Florencio, Shleifer, Andrei, and Robert W. Vishny. 1998. "Law and Finance," Journal of Political Economy, 106, 1113-1155.

,--1, and $\longrightarrow$. 2000. "Investor Protections and Corporate Governance," Journal of Financial Economics, 58, 3-27.

LaPorta, Rafael, Lopez-de-Silanes, Florencio, and Andrei Shleifer. 1999. "Corporate Ownership Around the World," Journal of Finance, 64, 471-517.

Majewski, John. 1996. "Who Financed the Transportation Revolution? Regional Divergence and Internal Improvements in Antebellum Pennsylvania and Virginia," Journal of Economic History, 56, 763-788.

Meissner, Christopher M. 2005. "Voting Rules and the Success of Connected Lending in 19th Century New England Banks," Explorations in Economic History, 42, 509-528.

Miller, Nathan. 1962. The Enterprise of a Free People: Aspects of Economic Development in New York State During the Canal Period, 1792-1868. Ithaca: Cornell University Press.

Morck, Randall, Shleifer, Andrei, and Robert Vishny. 1988. "Management Ownership and Market Valuation: An Empirical Analysis," Journal of Financial Economics, 20, 293-315.

Myers, Margaret G. 1931. The New York Money Market. Nw York: Columbia University Press.

Oneida Manufacturing Society. 1820-56. Manuscript directors' minutes. Oneida County Historical Society, Utica NY.

Ratner, David L. 1970. "The Government of Business Corporations: Critical Reflections on the Rule of One Share, One Vote," Cornell Law Review, 56, 1-56.

Roe, Mark J. 1994. Strong Managers, Weak Owners. Princeton: Princeton University Press.

Rousseau, Peter L., and Richard Sylla. 2005. "Emerging Financial Markets and Early U.S. Growth," Explorations in Economic History, 42, 1-26.

Scott, William R. 1912. The Constitution and Finance of English, Scottish, and Irish Joint-Stock Companies to 1720. Cambridge: The University Press.

Seavoy, Ronald E. 1982. The Origins of the American Business Corporation, 1784-1855. Westport, CT: Greenview Press. 
Sylla, Richard E., Wilson, Jack W., and Robert E. Wright. 2005. Price Quotations in Early United States Securities Markets, 1790-1860. ICPSR04053-v1. Ann Arbor, MI: Inter-university Consortium for Political and Social Research, 2005-08-24.

Villalonga, Belen and Raphael Amit. 2006. "Benefits and Costs of Control-Enhancing Mechanisms in U.S. Family Firms," Working Paper, Harvard Business School.

Wallis, John. 2003. "Market-Augmenting Government? States and Corporations in NineteenthCentury America," in Azfar and Cadwell, eds., Market-Augmenting Government. Ann Arbor: University of Michigan Press.

Werner, Walter. 1986. "Corporate Law In Search of Its Future," Columbia Law Review, 81, 1610-1666.

Werner, Walter, and Steven T. Smith. 1991. Wall Street. New York: Columbia University Press.

Whitestown Cotton \& Wollen Manufacturing Society. Manuscript stock ledger. Oneida County Historical Society, Utica NY.

Wright, Robert E. 1999. "Bank Ownership and Lending Patterns in New York and Pennsylvania, 1781-1831," Business History Review, 73, 40-60.

2005. The First Wall Street: Chestnut Street, Philadelphia and the Birth of American Finance. Chicago: University of Chicago Press. 


\section{Data Appendix}

\section{The Charters}

812 charters of incorporation were granted to businesses in New York prior to 1826. The 659 charters granted via special act of the legislature were found and coded from New York's session laws (Laws of New York, 1790-1825.) A substantial fraction of these charters were subsequently amended, often to increase the capital stock. The dataset includes the terms of the charters as amended as of 1825. For the 153 firms incorporated under New York's 1811 general incorporation act for manufacturing firms, the certificates of incorporation were found in the records of the New York State Comptroller in the New York State Archives, Albany NY (record group A1859).

\section{New York's 1823 Capital Tax and the Shareholder Lists}

In 1823, New York levied a tax on the paid-in capital of incorporated companies, payable by the corporations themselves (Laws of New York, 1823, Ch. 262). The law was revised in 1824 and again in 1825 in response to difficulties encountered in its implementation (Laws of New York, 1824, Ch. 22; 1825, Ch. 254.) The evolution of these laws, and the difficulties encountered in their implementation, are discussed in the report of the comptroller on the taxation of incorporated companies (New York Assembly Journal, 1827, p. 538-549). The law required that all incorporated companies submit a list of the names, places of residence, and numbers of shares owned, for all stockholders, to the state comptroller, so that revenues could be distributed to county governments in proportion to the amount of stock owned in each county. The law remained in effect until 1828, when it was replaced with a simpler capital tax on corporations that did not provide for revenue distribution on the basis of local shareholdings (New York Revised Statutes, 1828, chapter 13, title $4)$.

The lists of stockholders submitted by the corporations pursuant to the tax law were found in various different record groups in the New York State Archives associated with the comptroller's office, including A0833, A0829, and A0847. The comptroller's ledgers of taxes paid by incorporated companies pursuant to the law, and amounts allocated to the different counties on the basis of the residences of their shareholders, were found within record group A1301; the ledgers recording the results of the comptroller's attempts to determine whether chartered corporations were in operation were found in record group A1204. The comptroller's records indicate that compliance with the law was initially low, but by 1826 most of the corporations believed to be in operation were submitting the required stockholder lists. As a stockholder list could be found for at least one year for less than half of the 282 operating corporations; this implies that most of these lists have not survived. Although the staff at the New York State Archives can not be certain about the reason for these losses, they have indicated that the fire at the state library in 1911, coupled with the destruction of many historical records by the state archivist in the 1950s, are the likely causes. In an effort to expand the scope of the dataset, an extensive search of various archives in New York State was undertaken to try to find duplicate copies of the stockholder lists that may have been retained by the corporations themselves in their correspondence files. A small number of these shareholder lists found in the New York State Historical Association, Cooperstown NY, and the Citigroup Archives, New York NY. 


\section{Summary Statistics}

Summary statistics for the variables used in the analysis in the paper are presented in the table below. Note that the statistics for the governance provisions are those pertaining to the 132 observations where ownership lists could be found.

\begin{tabular}{|c|c|c|c|c|}
\hline & Mean & Std. Dev. & Min & Max \\
\hline \multicolumn{5}{|l|}{ Governance Provisions } \\
\hline Voting rights index $\left(V_{i}\right)$ & .831 & .337 & .001 & 1 \\
\hline Mandatory dividend & .151 & - & 0 & 1 \\
\hline Annual financial statements & .222 & - & 0 & 1 \\
\hline Number on board & 11.793 & 11.443 & 3 & 92 \\
\hline $\log ($ paid-in capital) & 11.146 & 1.580 & 6.620 & 14.533 \\
\hline $\log ($ firm age $)$ & 1.887 & 1.055 & 0 & 3.367 \\
\hline \multicolumn{5}{|l|}{ Ownership Structure (Table 5) } \\
\hline Percent of stock held by top $10 \%$ of shareholders & .477 & .170 & .169 & .962 \\
\hline Percent of votes held by top $10 \%$ of shareholders & .437 & .178 & .1 & .962 \\
\hline $\log ($ number of shareholders) & 3.640 & 1.239 & 1.099 & 6.328 \\
\hline $\log ($ number of counties in which the stock is held) & 1.284 & .749 & 0 & 2.996 \\
\hline Percent of stockholders with surname in common with another & .264 & .174 & 0 & 1 \\
\hline \multicolumn{5}{|l|}{ Managerial Control (Table 6) } \\
\hline Percent of stock held by board (directly \& indirectly) & .418 & .241 & .062 & .933 \\
\hline Percent of votes held by board (directly \& indirectly) & .395 & .239 & .049 & .933 \\
\hline Percent of votes held by outside $5 \%$ blockholders & .071 & .010 & 0 & .358 \\
\hline Margin of managerial control & .324 & .250 & -.113 & .933 \\
\hline \multicolumn{5}{|l|}{ Firm Value (Table 7) } \\
\hline Firm value (average market-to-book value for 1826 ) & 88.756 & 24.515 & 38.254 & 150.855 \\
\hline
\end{tabular}

\section{Managerial Ownership Data}

Lists of directors were found by searching all New York City and many New York State newspapers where issues from the year 1826 survive. The newspapers in which the identities of directors were found were the Albany Argus, New York Evening Post, New York Enquirer, New York American, Journal of Commerce, and the New York Commercial Advertiser. In addition, city directories for New York and Albany contained a few lists of directors. These were supplemented with lists of directors found in the minute books of corporations held a the following institutions: Citigroup Archives, New York NY; Oneida County Historical Society, Utica NY; SUNY Albany Library, Albany NY; the New York State Historical Association, Cooperstown NY; and the New-York Historical Society, New York NY. 